\title{
LEVEL II SCOUR ANALYSIS FOR BRIDGE 14 (WRUTTH00170014) on TOWN HIGHWAY 17, crossing the CLARENDON RIVER, WEST RUTLAND, VERMONT
}

Open-File Report 98-420

Prepared in cooperation with

VERMONT AGENCY OF TRANSPORTATION

and

FEDERAL HIGHWAY ADMINISTRATION

U.S. Department of the Interior

U.S. Geological Survey

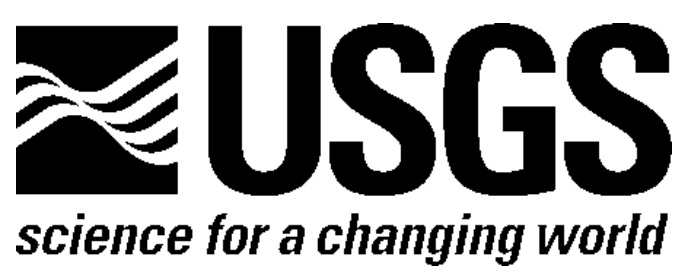


LEVEL II SCOUR ANALYSIS FOR

BRIDGE 14 (WRUTTH00170014) on

TOWN HIGHWAY 17, crossing the

CLARENDON RIVER,

WEST RUTLAND, VERMONT

By RONDA L. BURNS and ERICK M. BOEHMLER

U.S. Geological Survey

Open-File Report 98-420

Prepared in cooperation with

VERMONT AGENCY OF TRANSPORTATION

and

FEDERAL HIGHWAY ADMINISTRATION 


\title{
U.S. DEPARTMENT OF THE INTERIOR BRUCE BABBITT, Secretary
}

\author{
U.S. GEOLOGICAL SURVEY
}

Thomas J. Casadevall, Acting Director

For additional information write to:

District Chief

U.S. Geological Survey 361 Commerce Way

Pembroke, NH 03275-3718
Copies of this report may be purchased from:

U.S. Geological Survey

Branch of Information Services

Open-File Reports Unit

Box 25286

Denver, CO 80225-0286 


\section{CONTENTS}

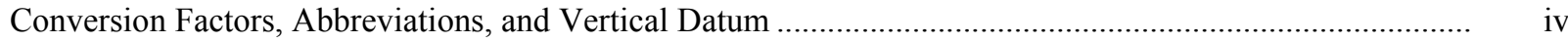

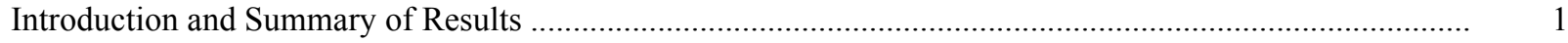

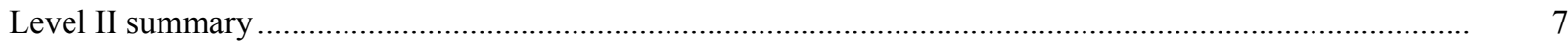

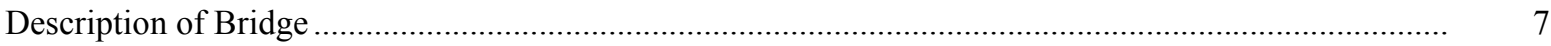

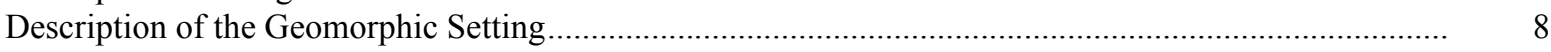

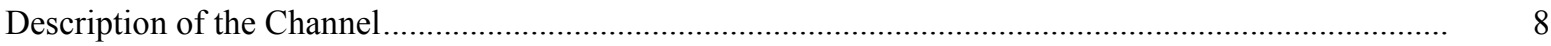

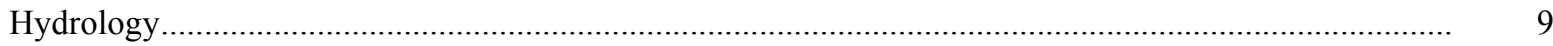

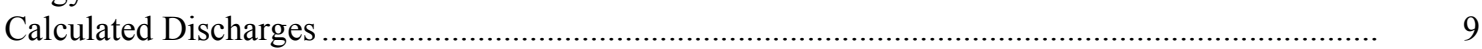

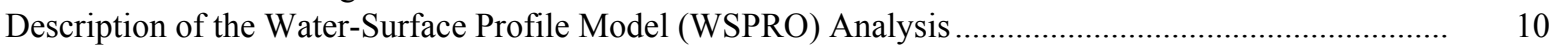

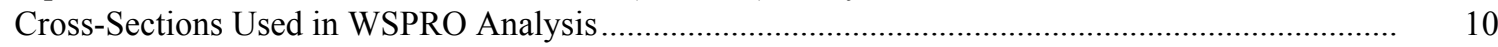

Data and Assumptions Used in WSPRO Model ........................................................................ 11

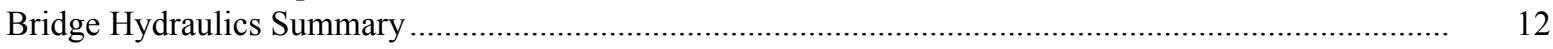

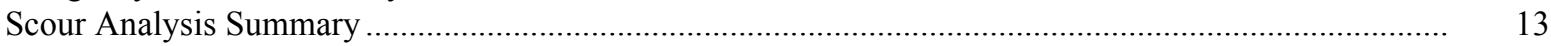

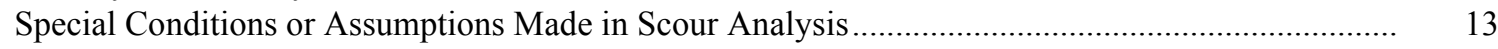

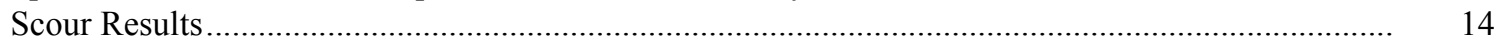

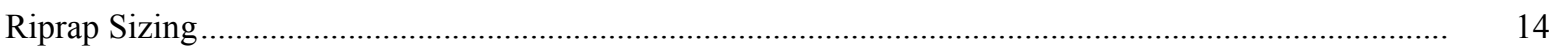

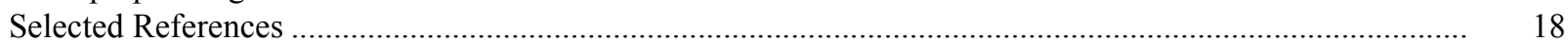

Appendices:

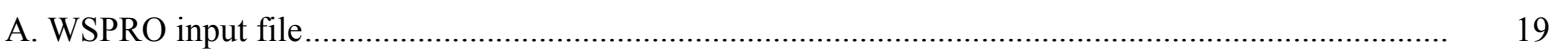

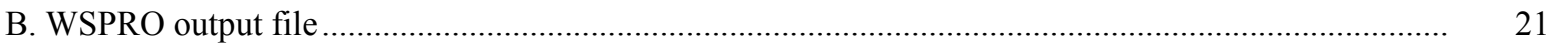

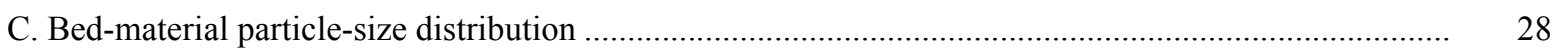

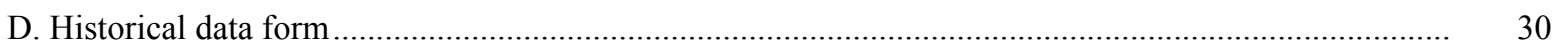

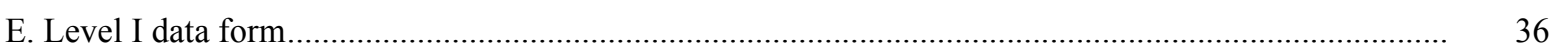

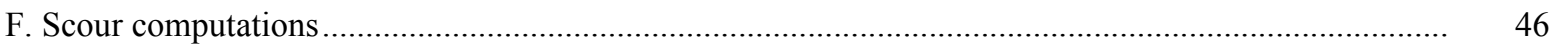

\section{FIGURES}

1. Map showing location of study area on USGS 1:24,000 scale map

2. Map showing location of study area on Vermont Agency of Transportation town highway map

3. Structure WRUTTH00170014 viewed from upstream (September 21, 1995)

4. Downstream channel viewed from structure WRUTTH00170014 (September 21, 1995)

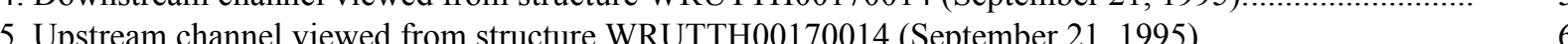

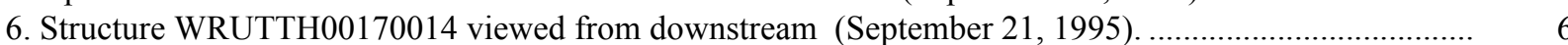

7. Water-surface profiles for the 100- and 500-year discharges at structure

WRUTTH00170014 on Town Highway 17, crossing the Clarendon River,

West Rutland, Vermont.....

8. Scour elevations for the 100- and 500-year discharges at structure

WRUTTH00170014 on Town Highway 17, crossing the Clarendon River,

West Rutland, Vermont.

\section{TABLES}

1. Remaining footing/pile depth at abutments for the 100-year discharge at structure WRUTTH00170014 on Town Highway 17, crossing the Clarendon River, West Rutland, Vermont.

2. Remaining footing/pile depth at abutments for the 500-year discharge at structure WRUTTH00170014 on Town Highway 17, crossing the Clarendon River, West Rutland, Vermont. 


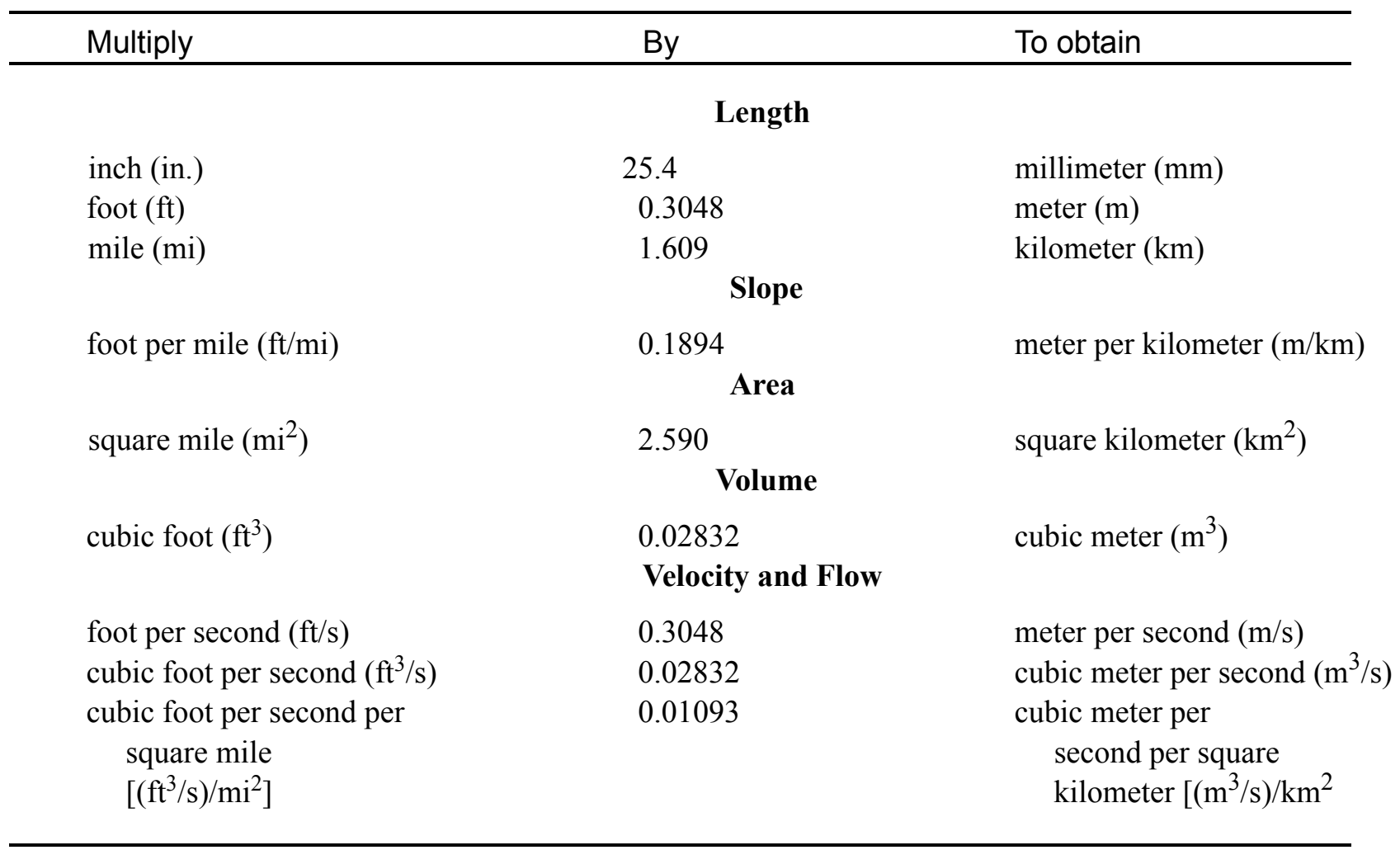

\section{OTHER ABBREVIATIONS}

$\begin{array}{lrlr}\mathrm{BF} & \text { bank full } & \text { LWW } & \text { left wingwall } \\ \mathrm{cfs} & \text { cubic feet per second } & \text { Max } & \text { maximum } \\ \mathrm{D}_{50} & \text { median diameter of bed material } & \text { MC } & \text { main channel } \\ \mathrm{DS} & \text { downstream } & \text { RAB } & \text { right abutment } \\ \mathrm{elev} & \text { elevation } & \text { RABUT } & \text { face of right abutment } \\ \mathrm{f} / \mathrm{p} & \text { flood plain } & \text { RB } & \text { right bank } \\ \mathrm{ft} & \text { square feet } & \text { ROB } & \text { right overbank } \\ \mathrm{ft} / \mathrm{ft} & \text { feet per foot } & \text { RWW } & \text { right wingwall } \\ \mathrm{FEMA} & \text { Federal Emergency Management Agency } & \text { TH } & \text { town highway } \\ \mathrm{FHWA} & \text { Federal Highway Administration } & \text { UB } & \text { under bridge } \\ \mathrm{JCT} & \text { junction } & \text { US } & \text { upstream } \\ \text { LAB } & \text { left abutment } & \text { USGS } & \text { United States Geological Survey } \\ \text { LABUT } & \text { face of left abutment } & \text { VTAOT } & \text { Vermont Agency of Transportation } \\ \text { LB } & \text { left bank } & \text { WSPRO } & \text { water-surface profile model } \\ \text { LOB } & \text { left overbank } & \text { yr } & \text { year }\end{array}$

In this report, the words "right" and "left" refer to directions that would be reported by an observer facing downstream. Sea level: In this report, "sea level" refers to the National Geodetic Vertical Datum of 1929-- a geodetic datum derived from a general adjustment of the first-order level nets of the United States and Canada, formerly called Sea Level Datum of 1929.

In the appendices, the above abbreviations may be combined. For example, USLB would represent upstream left bank. 


\title{
LEVEL II SCOUR ANALYSIS FOR BRIDGE 14 (WRUTTH00170014) ON TOWN HIGHWAY 17, CROSSING THE CLARENDON RIVER, WEST RUTLAND, VERMONT
}

\author{
By Ronda L. Burns and Erick M. Boehmler
}

\section{INTRODUCTION AND SUMMARY OF RESULTS}

This report provides the results of a detailed Level II analysis of scour potential at structure WRUTTH00170014 on Town Highway 17 crossing the Clarendon River, West Rutland, Vermont (figures 1-8). A Level II study is a basic engineering analysis of the site, including a quantitative analysis of stream stability and scour (FHWA, 1993). Results of a Level I scour investigation also are included in appendix E of this report. A Level I investigation provides a qualitative geomorphic characterization of the study site. Information on the bridge, gleaned from Vermont Agency of Transportation (VTAOT) files, was compiled prior to conducting Level I and Level II analyses and is found in appendix D.

The site is in the Taconic section of the New England physiographic province in westcentral Vermont. The $40.9-\mathrm{mi}^{2}$ drainage area is in a predominantly rural and forested basin. In the vicinity of the study site, the surface cover is pasture downstream of the bridge and on the right bank upstream, with tree cover on the immediate banks. The upstream left bank is forested.

In the study area, the Clarendon River has a meandering channel with a slope of approximately $0.003 \mathrm{ft} / \mathrm{ft}$, an average channel top width of $36 \mathrm{ft}$ and an average bank height of $2 \mathrm{ft}$. The channel bed material ranges from sand to cobble with a median grain size $\left(\mathrm{D}_{50}\right)$ of $29.9 \mathrm{~mm}(0.098 \mathrm{ft})$. The geomorphic assessment at the time of the Level I and Level II site visit on September 21, 1995, indicated that the reach was laterally unstable. The upstream left and right banks and the downstream right bank have moderate fluvial erosion. There are also cut-banks upstream and downstream of the bridge.

The Town Highway 17 crossing of the Clarendon River is a 41-ft-long, one-lane bridge consisting of one 37-foot steel-stringer span (Vermont Agency of Transportation, written communication, March 15, 1995). The opening length of the structure parallel to the bridge face is $36.8 \mathrm{ft}$. The bridge is supported by vertical, concrete abutments with wingwalls. In addition, there is a $5 \mathrm{ft}$ diameter, steel, corrugated culvert located $50 \mathrm{ft}$ to the right of the bridge. The channel is skewed approximately zero degrees to the opening and the openingskew-to-roadway is zero degrees. 
A scour hole up to $2.0 \mathrm{ft}$ deeper than the mean thalweg depth was observed in the upstream channel, under the bridge, and in front of the stone fill along the downstream right wingwall during the Level I assessment. Scour protection measures at the site included type- 1 stone fill (less than 12 inches diameter) along the downstream left wingwall and type-2 stone fill (less than 36 inches diameter) along the upstream left bank, the upstream left and right wingwalls, the right abutment, the downstream right wingwall, and at the upstream end of the left abutment. Additional details describing conditions at the site are included in the Level II Summary and appendices D and E.

Scour depths and recommended rock rip-rap sizes were computed using the general guidelines described in Hydraulic Engineering Circular 18 (Richardson and Davis, 1995) for the 100- and 500-year discharges. In addition, the incipient roadway-overtopping discharge was determined and analyzed as another potential worst-case scour scenario. Total scour at a highway crossing is comprised of three components: 1) long-term streambed degradation; 2) contraction scour (due to accelerated flow caused by a reduction in flow area at a bridge) and; 3 ) local scour (caused by accelerated flow around piers and abutments). Total scour is the sum of the three components. Equations are available to compute depths for contraction and local scour and a summary of the results of these computations follows.

Contraction scour for all modelled flows ranged from 1.7 to $2.4 \mathrm{ft}$. The worst-case contraction scour occurred at the 500-year discharge. Left abutment scour ranged from 3.7 to $5.6 \mathrm{ft}$. Right abutment scour ranged from 11.7 to $18.1 \mathrm{ft}$. The worst-case abutment scour occurred at the 500-year discharge. Additional information on scour depths and depths to armoring are included in the section titled "Scour Results". Scoured-streambed elevations, based on the calculated scour depths, are presented in tables 1 and 2. A cross-section of the scour computed at the bridge is presented in figure 8. Scour depths were calculated assuming an infinite depth of erosive material and a homogeneous particle-size distribution.

Usually, computed scour depths are evaluated in combination with other information including (but not limited to) historical performance during flood events, the geomorphic stability assessment, existing scour protection measures, and the results of the hydraulic analyses. Therefore, scour depths adopted by VTAOT may differ from the computed values documented herein. 


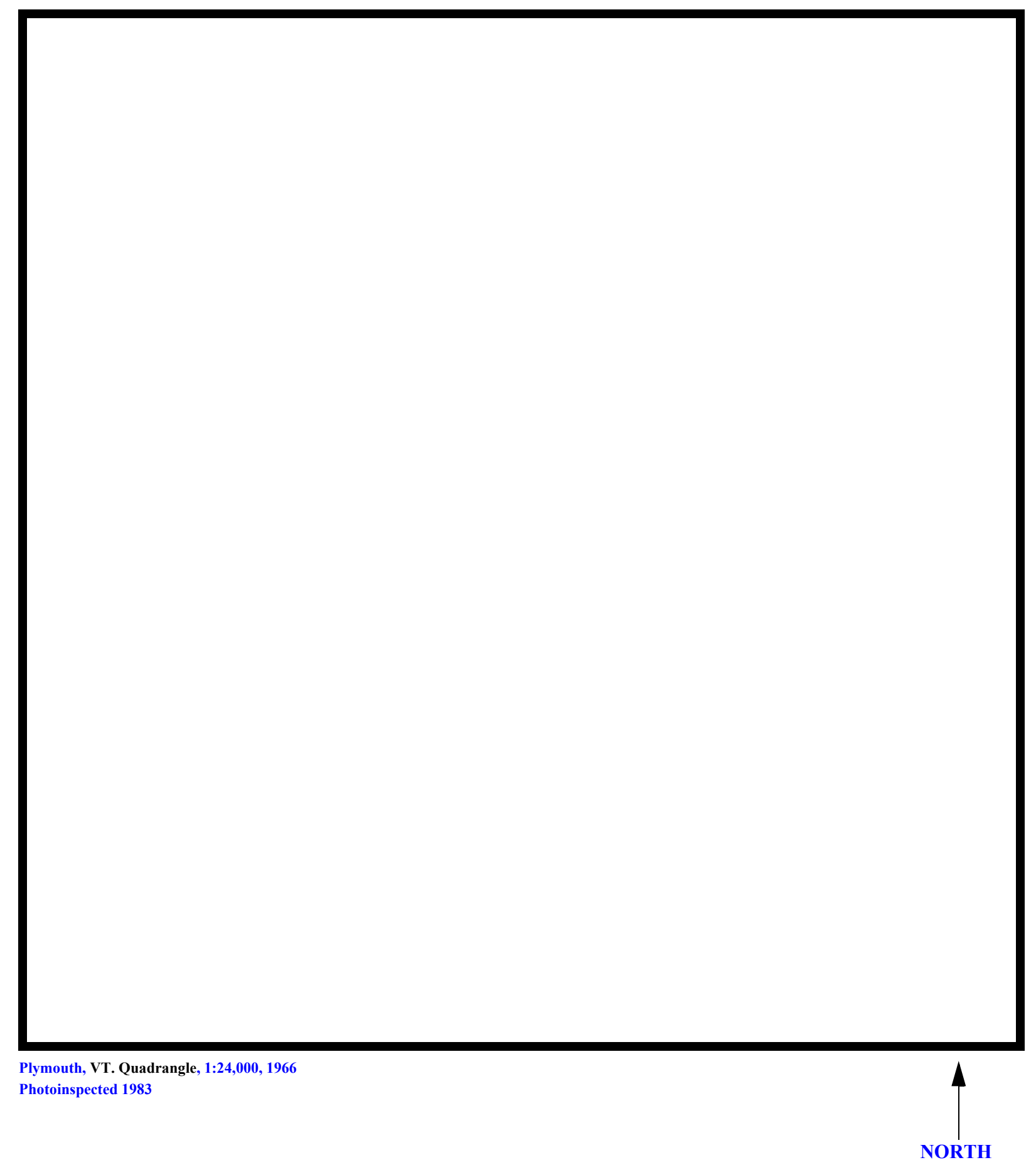

Figure 1. Location of study area on USGS 1:24,000 scale map. 
Figure 2. Location of study area on Vermont Agency of Transportation town highway map. 

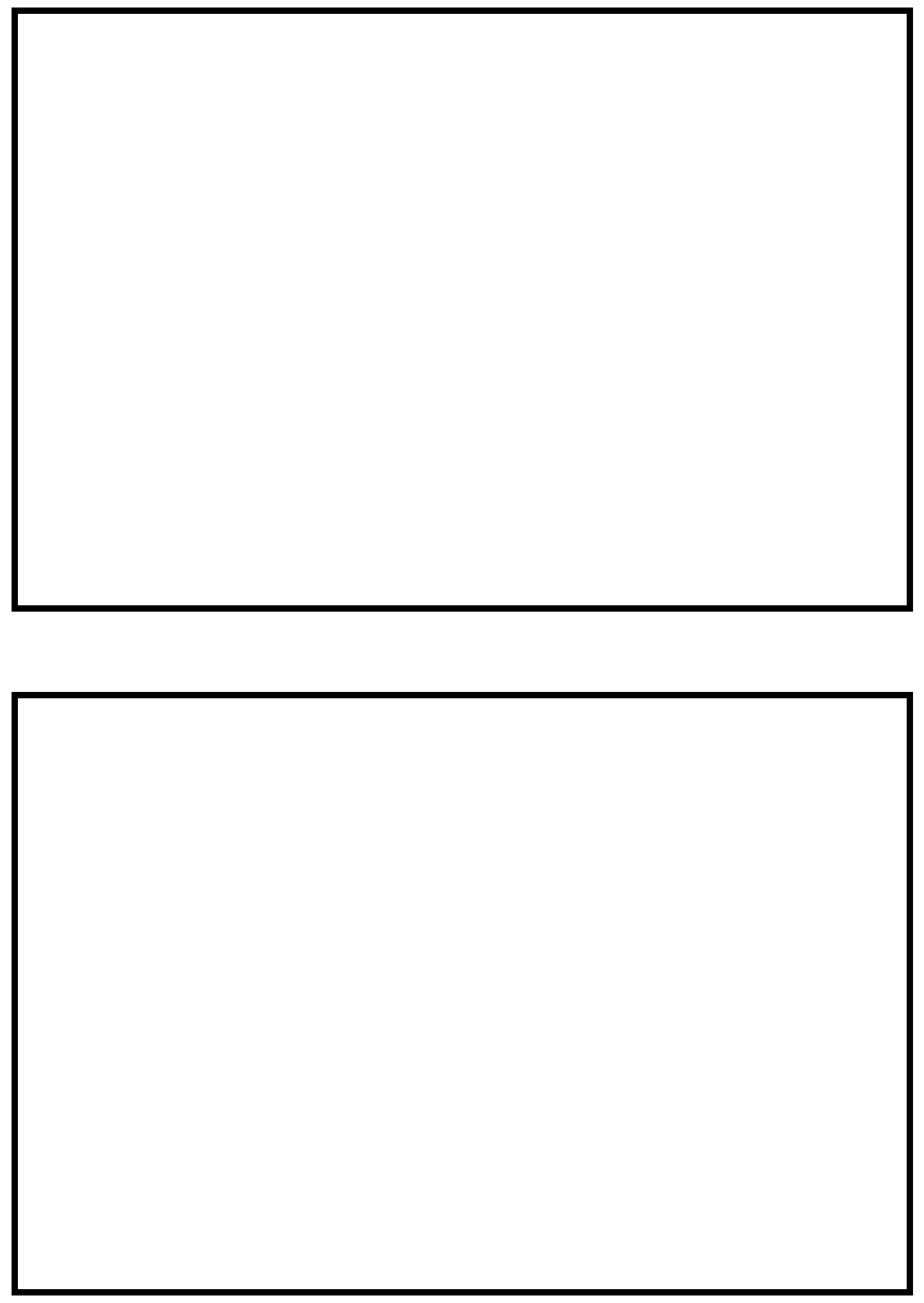

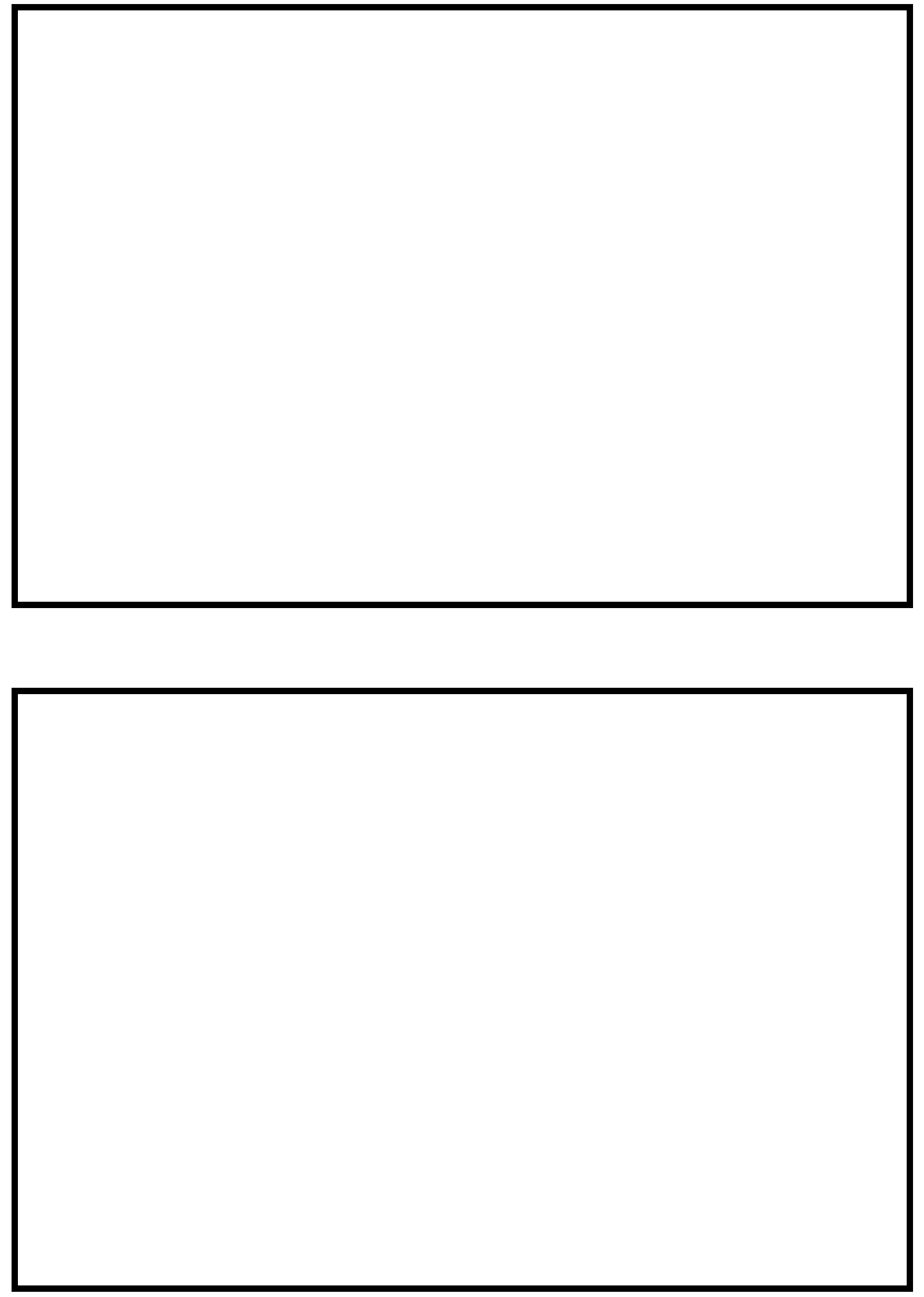


\section{LEVEL II SUMMARY}

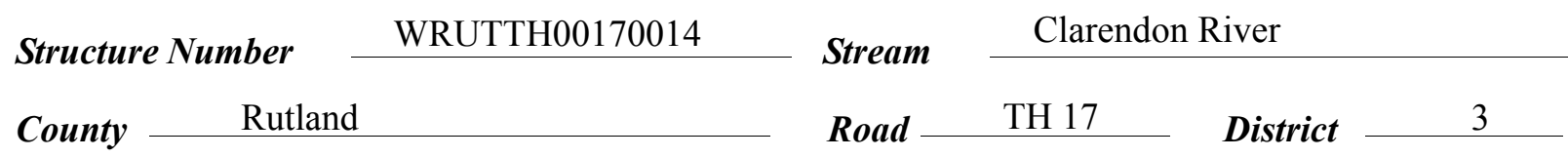

\section{Description of Bridge}

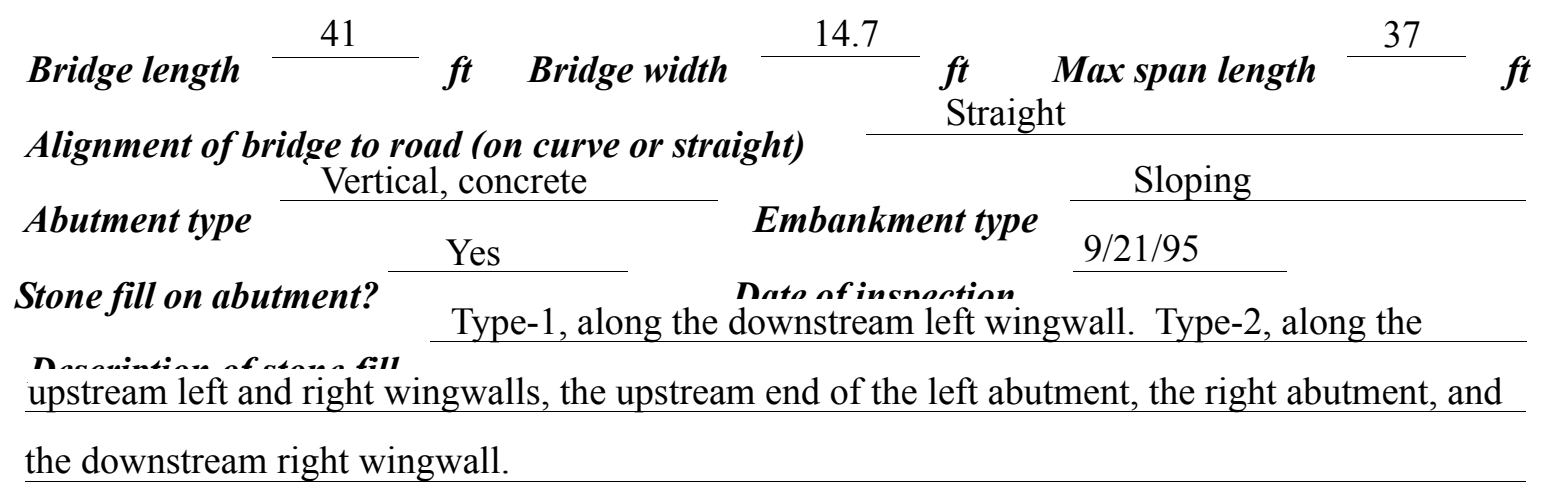

Abutments and wingwalls are concrete. There is a two

foot deep scour hole under the bridge along the stone fill for both abutments.

\begin{tabular}{l}
\hline Is bridge skewed to flood flow according to Yes ' survey? \\
No
\end{tabular}

Debris accumulation on bridge at time of Level I or Level II site visit:

\begin{tabular}{|c|c|c|c|}
\hline & $\begin{array}{c}\text { Date of insnortion } \\
9 / 21 / 95\end{array}$ & $\begin{array}{l}\text { Percent of almmual } \\
\text { blocked inortzontatly }\end{array}$ & $\begin{array}{l}\text { Percent of a n wel } \\
\text { blocked verticatty }\end{array}$ \\
\hline & $9 / 21 / 95$ & 0 & 0 \\
\hline & High. Ther & ome debris in the upstr & annel. \\
\hline
\end{tabular}

Potential for debris

The stone fill protection along the abutments protrudes into the channel (observed on 9/21/95).

Doscriho anv, foaturos noar ar at tho hridos that mav, affoct flou, (includo ahsorvation dato) 


\section{Description of the Geomorphic Setting}

General topography The channel is located in a moderate relief valley with narrow flood plains.

Geomorphic conditions at bridge site: downstream (DS), upstream (US)

Date of inspection $\quad \underline{9 / 21 / 95}$

DS left: $\quad$ Narrow flood plain

DS right: $\quad$ Narrow flood plain to a moderately sloped valley wall

US left: $\quad$ Narrow flood plain

US right: $\quad$ Narrow flood plain to a moderately sloped valley wall

\section{Description of the Channel}

$\begin{array}{llll}\text { Average top width } & 36 & \text { Average depth } & \frac{2}{\text { Gravel/Sand }}{ }^{\text {ft }}\end{array}$

Predominant bed material Bank material Perennial and

meandering with alluvial channel boundaries and wide point bars.

$\underline{9 / 21 / 95}$

Vegetative co ${ }^{1}$ Trees and brush with grass on the overbank

DS left: $\quad$ Few trees with grass on the overbank

DS right: $\quad$ Trees and brush

US left: $\quad$ Trees and brush with grass on the overbank

US right:

No

Do banks appear stable? The upstream left and right banks and the downstream right bank have moderate fluvial erosion. There are also cut-banks upstream and downstream of the bridge.
date of observatton.

None were observed on 9/21/95.

Describe any obstructions in channel and date of observation. 


\title{
Hydrology
}

Drainage area $\quad \frac{40.9}{m_{i}{ }^{2}}$

Percentage of drainage area in physiographic provinces: (approximate)

Physiographic province/section New England/Taconic
Percent of drainage area 100

\begin{abstract}
Is drainage area considered rural or urban?
Rural None

urbanization:

Describe any significant
\end{abstract}

Is there a USGS gage on the stream of interest?
USGS gage description

No

USGS gage description

USGS gage number

Gage drainage area $\mathrm{mi}^{2}$

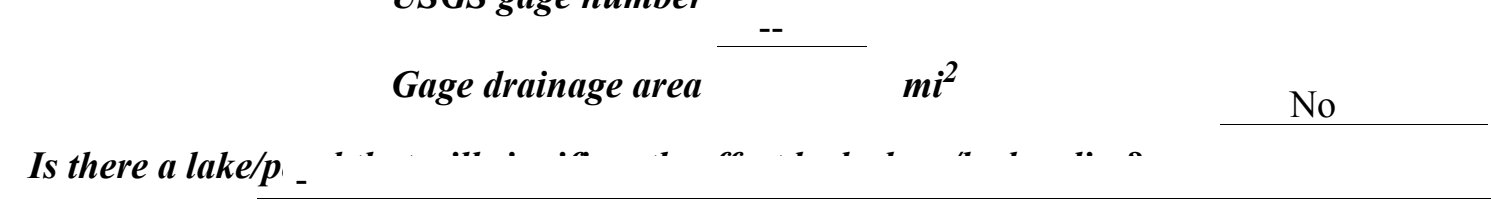

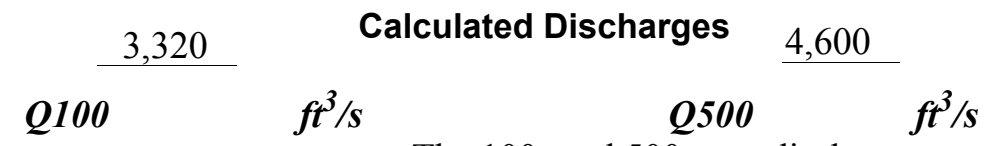

The 100- and 500-year discharges are based on flood

frequency estimates available from the VTAOT database (written communication, May 1995) for this site. The values used were within a range defined by flood frequency curves developed from several empirical methods (Benson, 1962; Johnson and Tasker, 1974; FHWA, 1983; Potter,

1957a\&b; Talbot, 1887). Each curve was extended graphically to the 500-year event. 


\section{Description of the Water-Surface Profile Model (WSPRO) Analysis}

Datum for WSPRO analysis (USGS survey, sea level, VTAOT plans) ～VTAOT plans

Datum tie between USGS survey and VTAOT plans The USGS arbitrary survey datum

was reduced by 399.04 to obtain the VTAOT plans' datum.

Description of reference marks used to determine USGS datum. $\quad$ RM1 is a chiseled X on top of the upstream end of the left abutment (elev. $100.87 \mathrm{ft}$, VTAOT plans' datum). RM2 is a chiseled X on top of the downstream end of the right abutment (elev. $100.85 \mathrm{ft}$, VTAOT plans'

datum). $\mathrm{RM} 3$ is a spike $5 \mathrm{ft}$ above the ground in a locust tree located $21.5 \mathrm{ft}$ to the left of the upstream end of the left abutment (elev. $104.84 \mathrm{ft}$, VTAOT plans' datum).

\section{Cross-Sections Used in WSPRO Analysis}

\begin{tabular}{cccl}
\hline${ }^{1}$ Cross-section & $\begin{array}{c}\text { Section } \\
\text { Reference } \\
\text { Distance } \\
\text { (SRD) } \text { in feet }\end{array}$ & $\begin{array}{c}{ }^{2} \text { Cross-section } \\
\text { development }\end{array}$ & \multicolumn{1}{c}{ Comments } \\
\hline EXIT1 & -38 & 1 & Exit section \\
FULLV & 0 & 2 & $\begin{array}{l}\text { Downstream Full-valley } \\
\text { section (Templated from } \\
\text { EXIT1) }\end{array}$ \\
BRIDG & 0 & 1 & Bridge section \\
RDWAY & 8 & 1 & Road Grade section \\
APPR1 & 53 & 1 & Approach section \\
\hline
\end{tabular}




\section{Data and Assumptions Used in WSPRO Model}

Hydraulic analyses of the reach were done by use of the Federal Highway Administration's WSPRO step-backwater computer program (Shearman and others, 1986, and Shearman, 1990). The analyses reported herein reflect conditions existing at the site at the time of the study. Furthermore, in the development of the model it was necessary to assume no accumulation of debris or ice at the site. Results of the hydraulic model are presented in the Bridge Hydraulic Summary, appendix B, and figure 7.

Channel roughness factors (Manning's " $n$ ") used in the hydraulic model were estimated using field inspections at each cross section following the general guidelines described by Arcement and Schneider (1989). Final adjustments to the values were made during the modelling of the reach. Channel " $n$ " values for the reach ranged from 0.030 to 0.046 , and overbank " $n$ " values ranged from 0.045 to 0.060 .

Normal depth at the exit section (EXIT1) was assumed as the starting water surface. This depth was computed by use of the slope-conveyance method outlined in the user's manual for WSPRO (Shearman, 1990). The slope used was $0.0031 \mathrm{ft} / \mathrm{ft}$, which was estimated from the appropriate topographic map (U.S. Geological Survey, 1964).

The surveyed approach section (APPR1) was modelled one bridge length upstream of the upstream face as recommended by Shearman and others (1986). This location provides a consistent method for determining scour variables.

For the incipient-overtopping discharge, WSPRO assumes critical depth at the bridge section. A supercritical model was developed for this discharge. After analyzing both the supercritical and subcritical profiles for this discharge, it was determined that the water surface profile does pass through critical depth within the bridge opening. Thus, the assumption of critical depth at the bridge is a satisfactory solution.

Culvert routines provided with WSPRO are not fully integrated. Therefore, it was necessary to develop individual ratings for the culvert and bridge to model this multipleopening situation. The ratings were combined to determine the quantity of the total discharge diverted from the bridge through the culvert. The combined ratings indicate the culvert diverts $6.9 \%$ of the total peak discharge on average. Each modelled discharge was reduced by the flow through the culvert for the model provided in appendix A and B. 


\section{Bridge Hydraulics Summary}

$\begin{array}{llll}\text { Average bridge embankment elevation } & 101.1 & f t \\ \text { Average low steel elevation } & 98.7 & \boldsymbol{f t}\end{array}$

100-year discharge $\quad 3,320 \quad \mathrm{ft}^{3} / \mathrm{s}$

Water-surface elevation in bridge opening

Road overtopping? ___ Yes Discharge over road _ $1,030 \mathrm{ft}^{3} / \mathrm{s}$

\begin{tabular}{llll} 
Area of flow in bridge opening & 237 & $\boldsymbol{f t}^{2}$ \\
\cline { 2 - 3 } Average velocity in bridge opening & 8.6 & $\boldsymbol{f t} / \mathrm{s}$
\end{tabular}

Maximum WSPRO tube velocity at bridge $\quad 10.7 \mathrm{ft} / \mathrm{s}$

Water-surface elevation at Approach section with bridge $\quad 100.7$

Water-surface elevation at Approach section without bridge $\quad\left[\begin{array}{c}{ }_{7} \\ \hdashline\end{array}\right.$

Amount of backwater caused by bridge

$3.4 i$

500-year discharge $\quad 4,600 \quad \mathrm{ft}^{3} / \mathrm{s}$

Water-surface elevation in bridge opening

$98.7 \mathrm{ft}$

Road overtopping? ___ Yes Discharge over road _ $2,090,3 / \mathbf{s}$

Area of flow in bridge opening _ـ $237 \quad \mathrm{ft}^{2}$

Average velocity in bridge opening $\quad 9.4 \mathrm{ft} / \mathrm{s}$

Maximum WSPRO tube velocity at bridge 11.6 's

Water-surface elevation at Approach section with bridge 101.3

Water-surface elevation at Approach section without bridge $\quad 97.8$

Amount of backwater caused by bridge $\quad 3.5, t$

Incipient overtopping discharge $\quad 1,910 \mathrm{ft}^{3} / \mathrm{s}$

Water-surface elevation in bridge opening $\quad 96.4 \quad$ t

Area of flow in bridge opening $\quad 152 \quad \mathrm{ft}^{2}$

Average velocity in bridge opening $11.6 \quad \mathrm{ft} / \mathrm{s}$

Maximum WSPRO tube velocity at bridge $15.0 \mathrm{ft} / \mathrm{s}$

Water-surface elevation at Approach section with bridge

Water-surface elevation at Approach section without bridge

Amount of backwater caused by bridge $\quad 2.1$, t

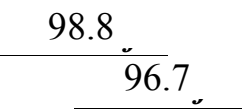




\section{Scour Analysis Summary}

\section{Special Conditions or Assumptions Made in Scour Analysis}

Scour depths were computed using the general guidelines described in Hydraulic Engineering Circular 18 (Richardson and Davis, 1995). Scour depths were calculated assuming an infinite depth of erosive material and a homogeneous particle-size distribution. The results of the scour analyses for the 100- and 500-year discharges are presented in tables 1 and 2 and the scour depths are shown graphically in figure 8 .

Contraction scour for the incipient roadway-overtopping discharge was computed by use of the Laursen clear-water contraction scour equation (Richardson and Davis, 1995, p. 32 , equation 20). At this site, the 100-year and 500-year discharges resulted in unsubmerged orifice flow. Contraction scour at bridges with orifice flow is best estimated by use of the Chang pressure-flow scour equation (oral communication, J. Sterling Jones, October 4, 1996). Thus, contraction scour for these discharges was computed by use of the Chang equation (Richardson and Davis, 1995, p. 145-146).

For comparison, contraction scour for the 100-year and 500-year discharges also was computed by use of the Laursen clear-water contraction scour equation and the Umbrell pressure-flow equation (Richardson and Davis, 1995, p. 144). Results from these computations are presented in appendix F. Furthermore, for the discharges which resulted in unsubmerged orifice flow, contraction scour was computed by substituting estimates for the depth of flow at the downstream bridge face in the contraction scour equations. Results with respect to these substitutions are also provided in appendix $\mathrm{F}$.

Abutment scour was computed by use of the HIRE equation (Richardson and Davis, 1995, p. 49, equation 29) because the HIRE equation is recommended when the length to depth ratio of the embankment blocking flow exceeds 25. Variables for the HIRE equation include the Froude number of the flow approaching the embankments, the length of the embankment blocking flow, and the depth of flow approaching the embankment less any roadway overtopping. 


\section{Scour Results}

Contraction scour:

Main channel

Live-bed scour

Clear-water scour

Depth to armoring

Left overbank

Right overbank

Local scour:

Abutment scour

Left abutment

Right abutment

Pier scour

Pier 1

Pier 2

Pier 3 100-year
discharge 500-year discharge

(Scour depths in feet)

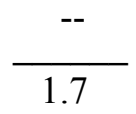

N/A
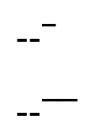

5.6

$18.1-$

$16.1-$
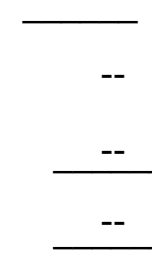

Incipient overtopping discharge 


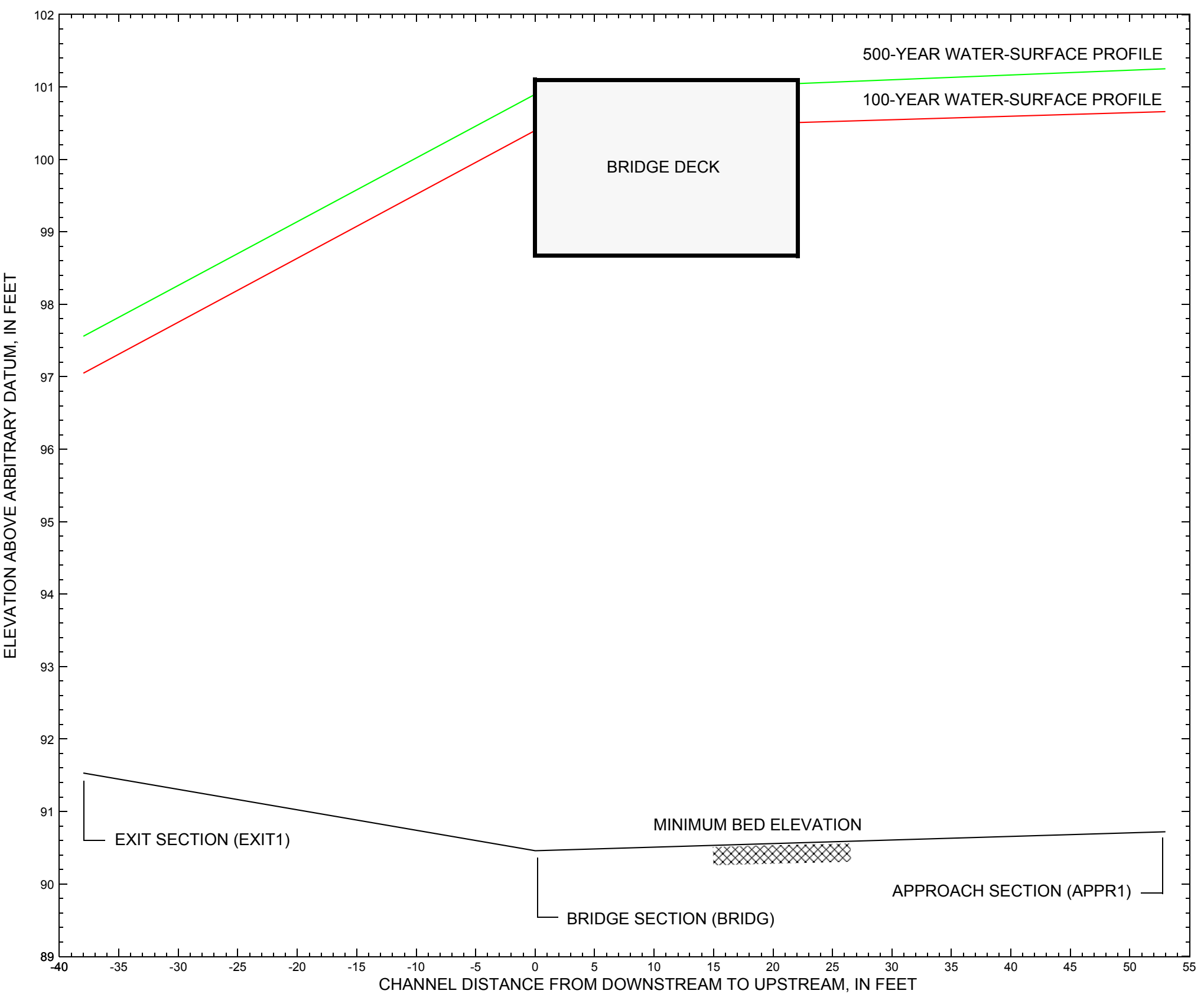

Figure 7. Water-surface profiles for the 100- and 500-year discharges at structure WRUTTH00170014 on Town Highway 17, crossing the Clarendon River, West Rutland, Vermont. 


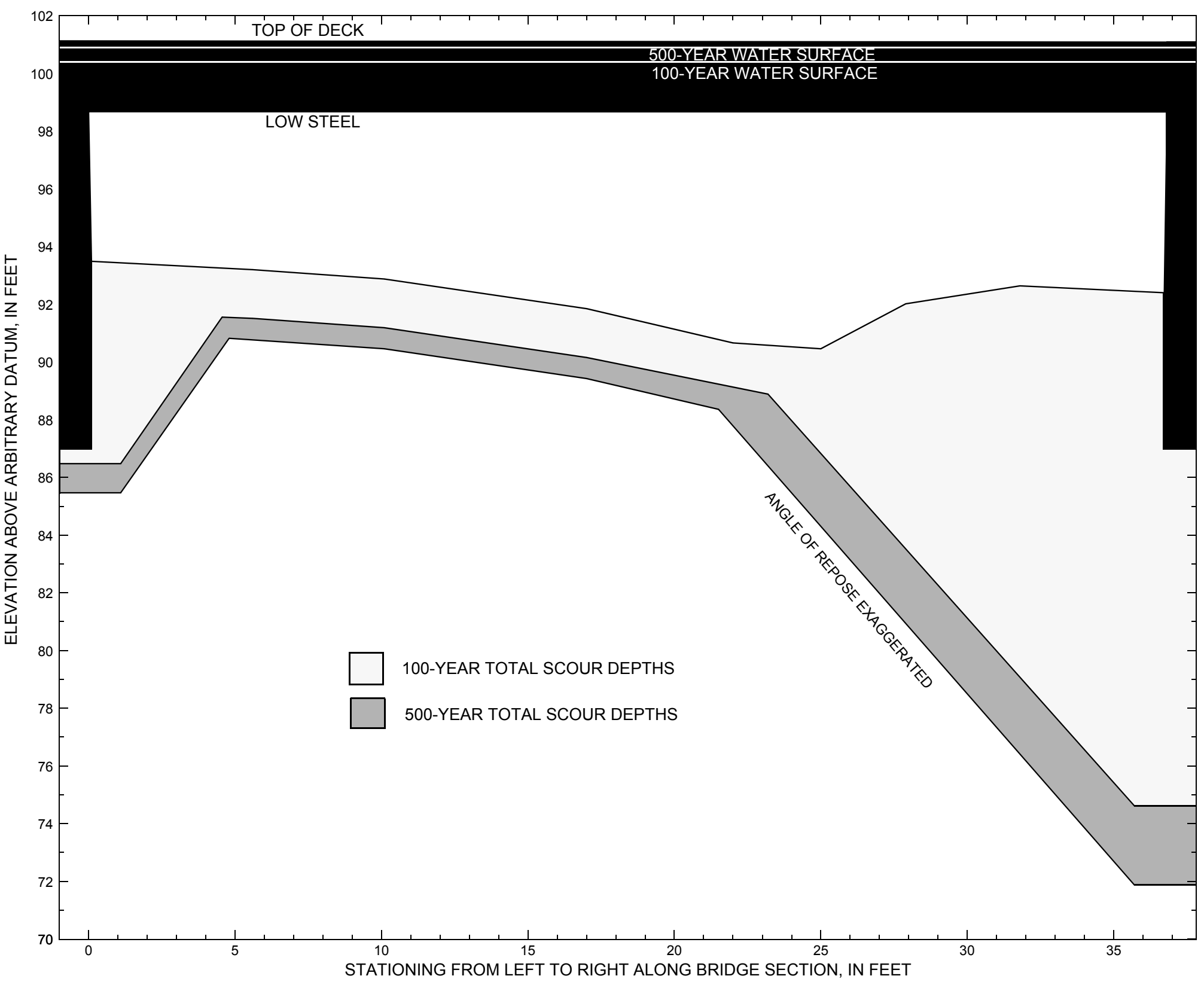

Figure 8. Scour elevations for the 100- and 500-year discharges at structure WRUTTH00170014 on Town Highway 17, crossing the Clarendon River, West Rutland, Vermont. 


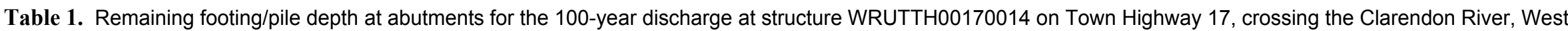
Rutland, Vermont.

[VTAOT, Vermont Agency of Transportation; --, no data]

\begin{tabular}{|c|c|c|c|c|c|c|c|c|c|c|c|}
\hline Description & Station $^{1}$ & $\begin{array}{l}\text { VTAOT } \\
\text { minimum } \\
\text { bridge seat } \\
\text { elevation } \\
\text { (feet) }\end{array}$ & $\begin{array}{l}\text { Surveyed } \\
\text { minimum } \\
\text { low-chord } \\
\text { elevation } \\
\text { (feet) }\end{array}$ & $\begin{array}{c}\text { Bottom of } \\
\text { footing/pile } \\
\text { elevation }{ }^{2} \\
\text { (feet) }\end{array}$ & $\begin{array}{c}\text { Channel } \\
\text { elevation at } \\
\text { abutment/ } \\
\text { pier }^{2} \\
\text { (feet) }\end{array}$ & $\begin{array}{l}\text { Contraction } \\
\text { scour depth } \\
\text { (feet) }\end{array}$ & $\begin{array}{l}\text { Abutment } \\
\text { scour } \\
\text { depth } \\
\text { (feet) }\end{array}$ & $\begin{array}{l}\text { Pier } \\
\text { scour } \\
\text { depth } \\
\text { (feet) }\end{array}$ & $\begin{array}{l}\text { Depth of } \\
\text { total scour } \\
\text { (feet) }\end{array}$ & $\begin{array}{c}\text { Elevation of } \\
\text { scour }^{2} \\
\text { (feet) }\end{array}$ & $\begin{array}{c}\text { Remaining } \\
\text { footing/pile } \\
\text { depth } \\
\text { (feet) }\end{array}$ \\
\hline \multicolumn{12}{|c|}{100 -year discharge is 3,320 cubic-feet per second } \\
\hline Left abutment & 0.0 & 98.6 & 98.7 & 87.0 & 93.5 & 1.7 & 5.3 & -- & 7.0 & 86.5 & -0.5 \\
\hline Right abutment & 36.8 & 98.6 & 98.7 & 87.0 & 92.4 & 1.7 & 16.1 & -- & 17.8 & 74.6 & -12.4 \\
\hline
\end{tabular}

1.Measured along the face of the most constricting side of the bridge.

2.Arbitrary datum for this study.

Table 2. Remaining footing/pile depth at abutments for the 500-year discharge at structure WRUTTH00170014 on Town Highway 17, crossing the Clarendon River, West Rutland, Vermont.

[VTAOT, Vermont Agency of Transportation; --, no data]

\begin{tabular}{|c|c|c|c|c|c|c|c|c|c|c|c|}
\hline Description & Station $^{1}$ & $\begin{array}{c}\text { VTAOT } \\
\text { minimum } \\
\text { bridge seat } \\
\text { elevation } \\
\text { (feet) }\end{array}$ & $\begin{array}{c}\text { Surveyed } \\
\text { minimum } \\
\text { low-chord } \\
\text { elevation } \\
\text { (feet) }\end{array}$ & $\begin{array}{c}\text { Bottom of } \\
\text { footing/pile } \\
\text { elevation }{ }^{2} \\
\text { (feet) }\end{array}$ & $\begin{array}{c}\text { Channel } \\
\text { elevation at } \\
\text { abutment/ } \\
\text { pier }^{2} \\
\text { (feet) }\end{array}$ & $\begin{array}{l}\text { Contraction } \\
\text { scour depth } \\
\text { (feet) }\end{array}$ & $\begin{array}{l}\text { Abutment } \\
\text { scour } \\
\text { depth } \\
\text { (feet) }\end{array}$ & $\begin{array}{l}\text { Pier } \\
\text { scour } \\
\text { depth } \\
\text { (feet) }\end{array}$ & $\begin{array}{l}\text { Depth of } \\
\text { total scour } \\
\text { (feet) }\end{array}$ & $\begin{array}{c}\text { Elevation of } \\
\text { scour }^{2} \\
\text { (feet) }\end{array}$ & $\begin{array}{c}\text { Remaining } \\
\text { footing/pile } \\
\text { depth } \\
\text { (feet) }\end{array}$ \\
\hline \multicolumn{12}{|c|}{500 -year discharge is 4,600 cubic-feet per second } \\
\hline Left abutment & 0.0 & 98.6 & 98.7 & 87.0 & 93.5 & 2.4 & 5.6 & -- & 8.0 & 85.5 & -1.5 \\
\hline Right abutment & 36.8 & 98.6 & 98.7 & 87.0 & 92.4 & 2.4 & 18.1 & -- & 20.5 & 71.9 & -15.1 \\
\hline
\end{tabular}

1.Measured along the face of the most constricting side of the bridge.

2.Arbitrary datum for this study. 


\section{SELECTED REFERENCES}

Arcement, G.J., Jr., and Schneider, V.R., 1989, Guide for selecting Manning's roughness coefficients for natural channels and flood plains: U.S. Geological Survey Water-Supply Paper 2339, 38 p.

Barnes, H.H., Jr., 1967, Roughness characteristics of natural channels: U.S. Geological Survey Water-Supply Paper 1849,213 p.

Benson, M. A., 1962, Factors Influencing the Occurrence of Floods in a Humid Region of Diverse Terrain: U.S. Geological Survey WaterSupply Paper 1580-B, 64 p.

Brown, S.A. and Clyde, E.S., 1989, Design of riprap revetment: Federal Highway Administration Hydraulic Engineering Circular No. 11, Publication FHWA-IP-89-016, 156 p.

Federal Highway Administration, 1983, Runoff estimates for small watersheds and development of sound design: Federal Highway Administration Report FHWA-RD-77-158.

Federal Highway Administration, 1993, Stream Stability and Scour at Highway Bridges: Participant Workbook: Federal Highway Administration Report FHWA-HI-91-011.

Froehlich, D.C., 1989, Local scour at bridge abutments in Ports, M.A., ed., Hydraulic Engineering--Proceedings of the 1989 National Conference on Hydraulic Engineering: New York, American Society of Civil Engineers, p. 13-18.

Hayes, D.C.,1993, Site selection and collection of bridge-scour data in Delaware, Maryland, and Virginia: U.S. Geological Survey WaterResources Investigation Report 93-4017, 23 p.

Interagency Advisory Committee on Water Data, 1982, Guidelines for determining flood flow frequency: U.S. Geological Survey, Bulletin 17B of the Hydrology Subcommittee, 190 p.

Johnson, C.G. and Tasker, G.D.,1974, Progress report on flood magnitude and frequency of Vermont streams: U.S. Geological Survey OpenFile Report 74-130, 37 p.

Lagasse, P.F., Schall, J.D., Johnson, F., Richardson, E.V., Chang, F., 1995, Stream Stability at Highway Structures: Federal Highway Administration Hydraulic Engineering Circular No. 20, Publication FHWA-IP-90-014, 144 p.

Laursen, E.M., 1960, Scour at bridge crossings: Journal of the Hydraulics Division, American Society of Civil Engineers, v. 86, no. HY2, p. 39-53.

Potter, W. D., 1957a, Peak rates of runoff in the Adirondack, White Mountains, and Maine woods area, Bureau of Public Roads

Potter, W. D., 1957b, Peak rates of runoff in the New England Hill and Lowland area, Bureau of Public Roads

Richardson, E.V. and Davis, S.R., 1995, Evaluating scour at bridges: Federal Highway Administration Hydraulic Engineering Circular No. 18, Publication FHWA-IP-90-017, 204 p.

Richardson, E.V., Simons, D.B., and Julien, P.Y., 1990, Highways in the river environment: Federal Highway Administration Publication FHWA-HI-90-016.

Ritter, D.F., 1984, Process Geomorphology: W.C. Brown Co., Debuque, Iowa, 603 p.

Shearman, J.O., 1990, User's manual for WSPRO--a computer model for water surface profile computations: Federal Highway Administration Publication FHWA-IP-89-027, 187 p.

Shearman, J.O., Kirby, W.H., Schneider, V.R., and Flippo, H.N., 1986, Bridge waterways analysis model; research report: Federal Highway Administration Publication FHWA-RD-86-108, 112 p.

Talbot, A.N., 1887, The determination of water-way for bridges and culverts.

U.S. Geological Survey, 1964, West Rutland, Vermont 7.5 Minute Series quadrangle map: U.S. Geological Survey Topographic Maps, Photorevised 1972, Scale 1:24,000. 


\section{APPENDIX A: \\ WSPRO INPUT FILE}




\section{WSPRO INPUT FILE}

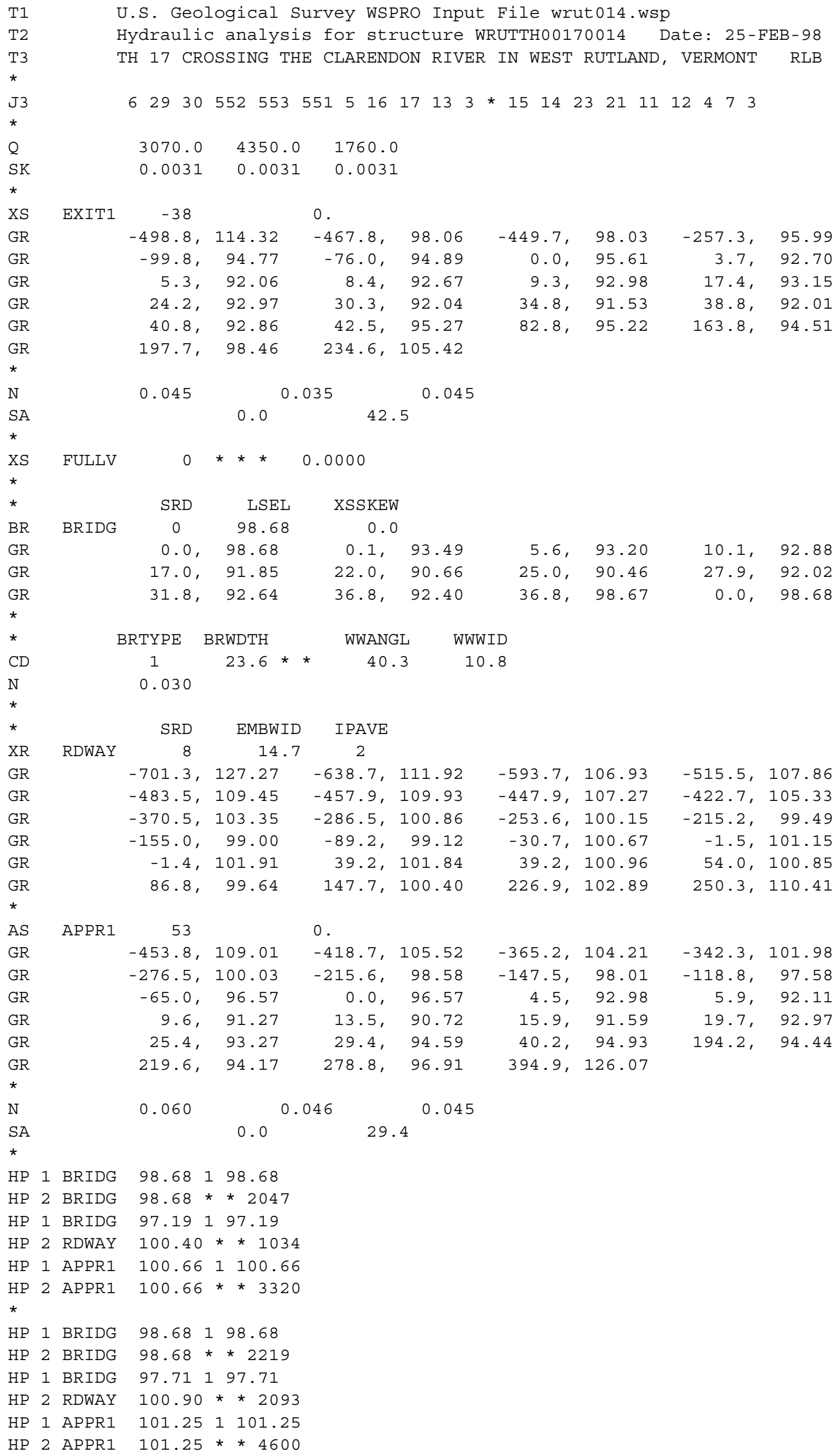




\section{APPENDIX B: \\ WSPRO OUTPUT FILE}




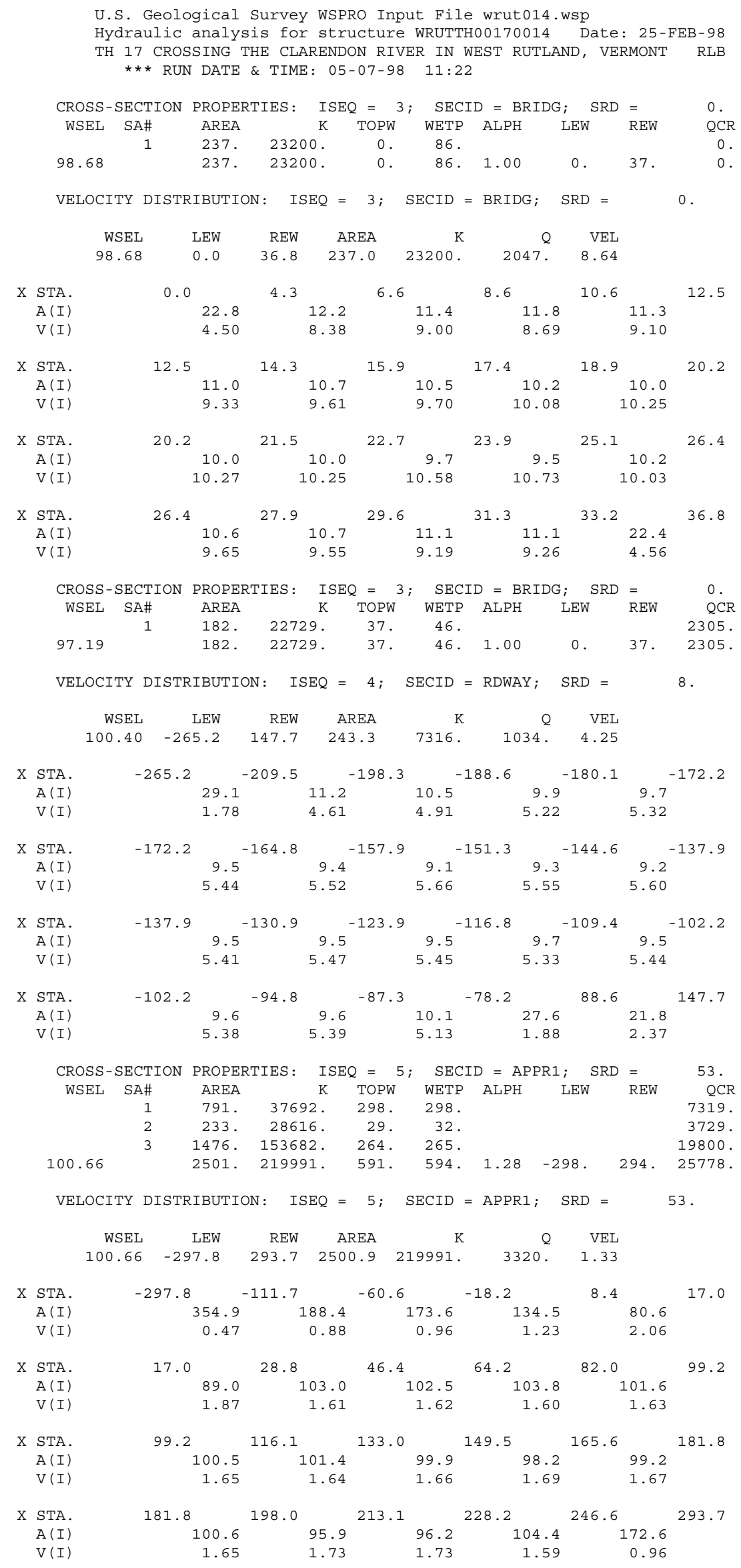




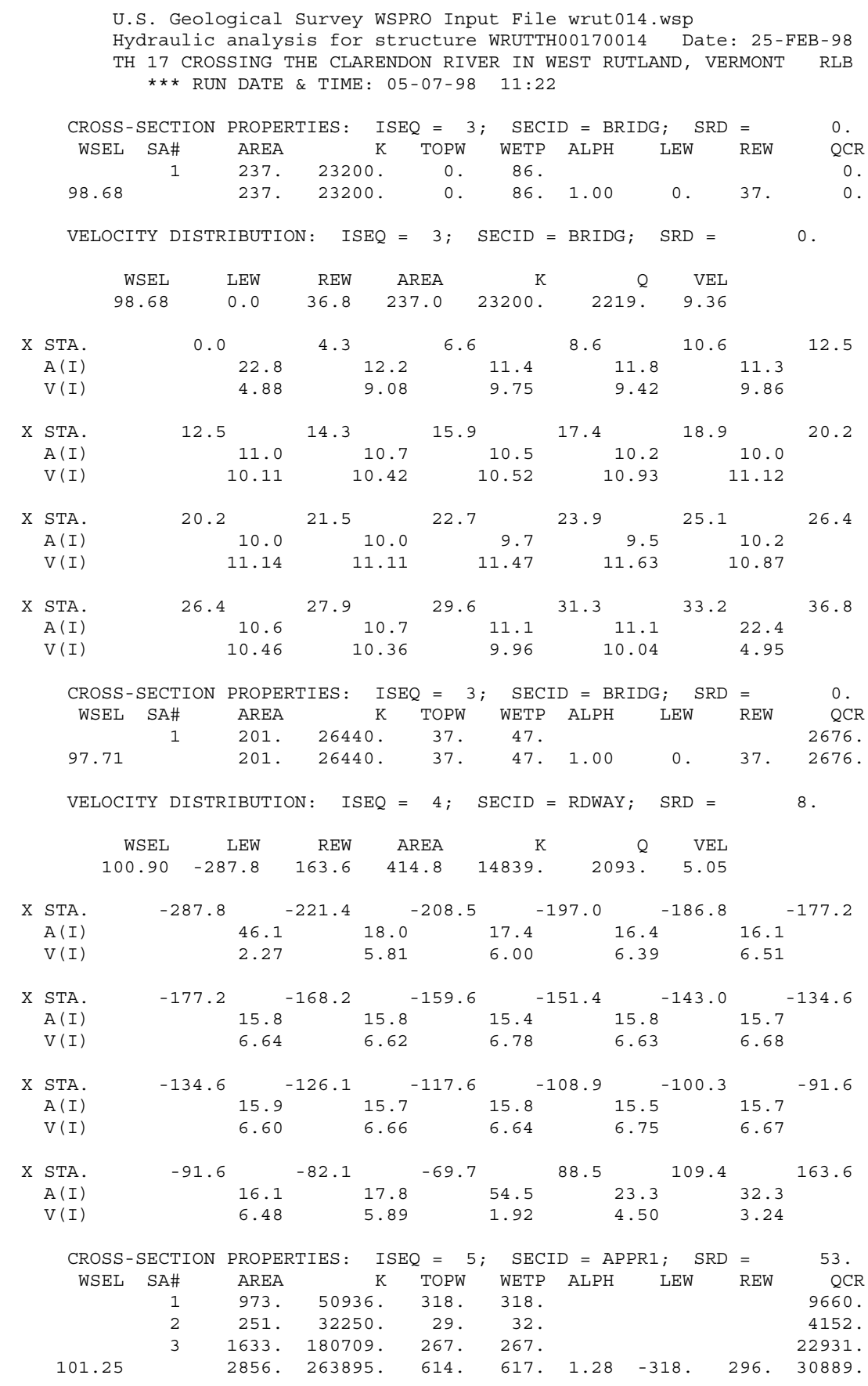

VELOCITY DISTRIBUTION: ISEQ $=5 ;$ SECID $=$ APPR1; $\quad$ SRD $=53$.

\begin{tabular}{|c|c|c|c|c|c|c|c|}
\hline & & WSEL & REW & REA & $Q$ & VEL & \\
\hline & & 101.25 & 296.1 & 263895 . & 4600 . & 1.61 & \\
\hline $\mathrm{x}$ & STA. & -317.7 & -130.3 & -75.5 & -35.3 & 4.1 & 13.8 \\
\hline & $A(I)$ & 402.8 & 217.6 & 187.0 & 191.6 & 93.8 & \\
\hline & $V(I)$ & 0.57 & 1.06 & 1.23 & 1.20 & 2.45 & \\
\hline $\mathrm{X}$ & STA. & 13.8 & 24.7 & 42.0 & 60.1 & 78.0 & 95.9 \\
\hline & $A(I)$ & 95.9 & 115.9 & 115.1 & 114.8 & 115.8 & \\
\hline & $V(I)$ & 2.40 & 1.98 & 2.00 & 2.00 & 1.99 & \\
\hline $\mathrm{X}$ & STA. & 95.9 & 113.3 & 130.7 & 147.7 & 164.3 & 180.8 \\
\hline & $A(I)$ & 113.5 & 114.5 & 112.8 & 110.7 & 111.8 & \\
\hline & $V(I)$ & 2.03 & 2.01 & 2.04 & 2.08 & 2.06 & \\
\hline $\mathrm{x}$ & STA. & 180.8 & 197.5 & 213.1 & 228.6 & 247.6 & 296.1 \\
\hline & $A(I)$ & 113.3 & 107.8 & 108.0 & 118.0 & 195.5 & \\
\hline & $\mathrm{V}(\mathrm{I})$ & 2.03 & 2.13 & 2.13 & 1.95 & 1.18 & \\
\hline
\end{tabular}


WSPRO OUTPUT FILE (continued)

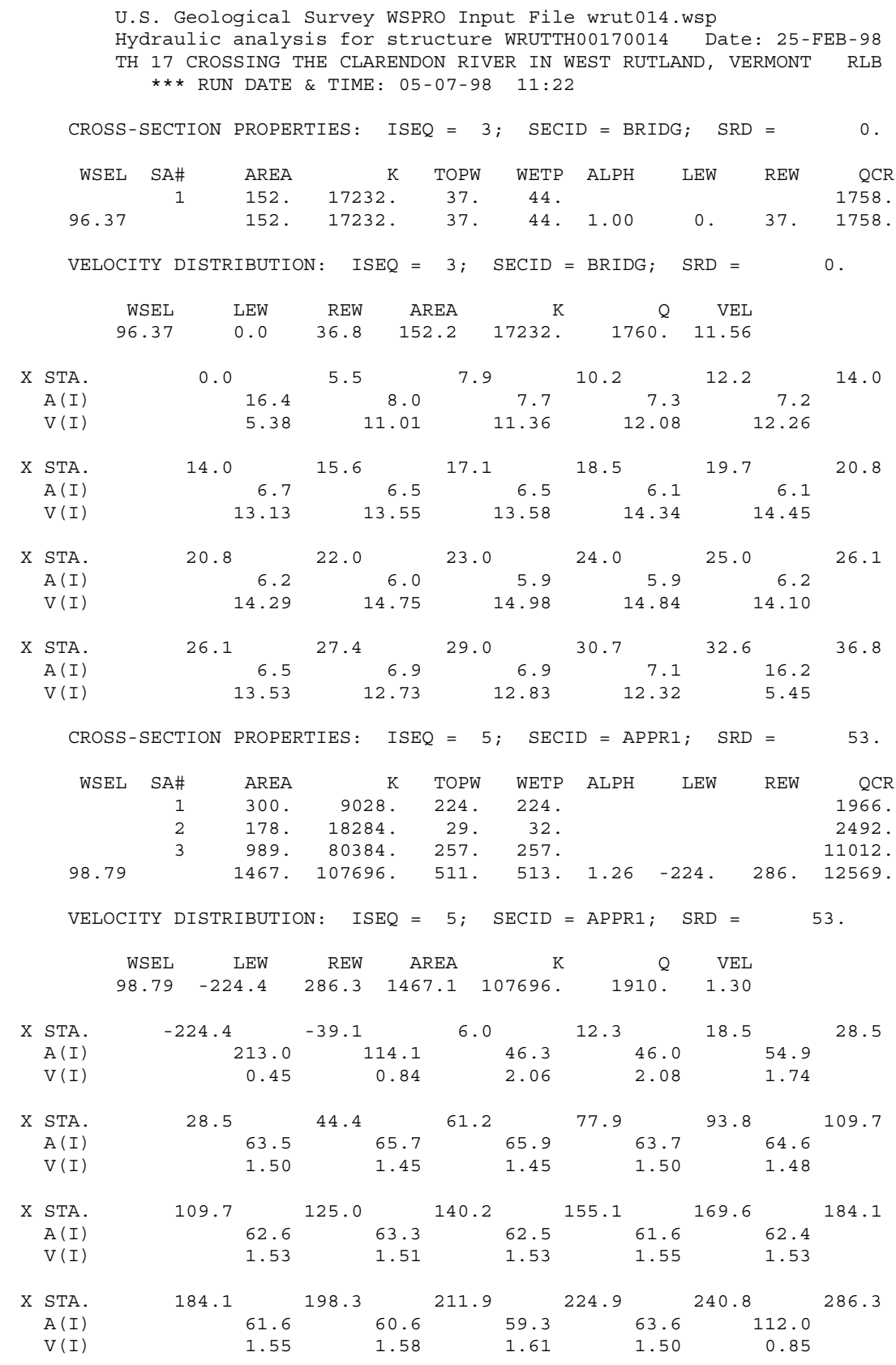


WSPRO OUTPUT FILE (continued)

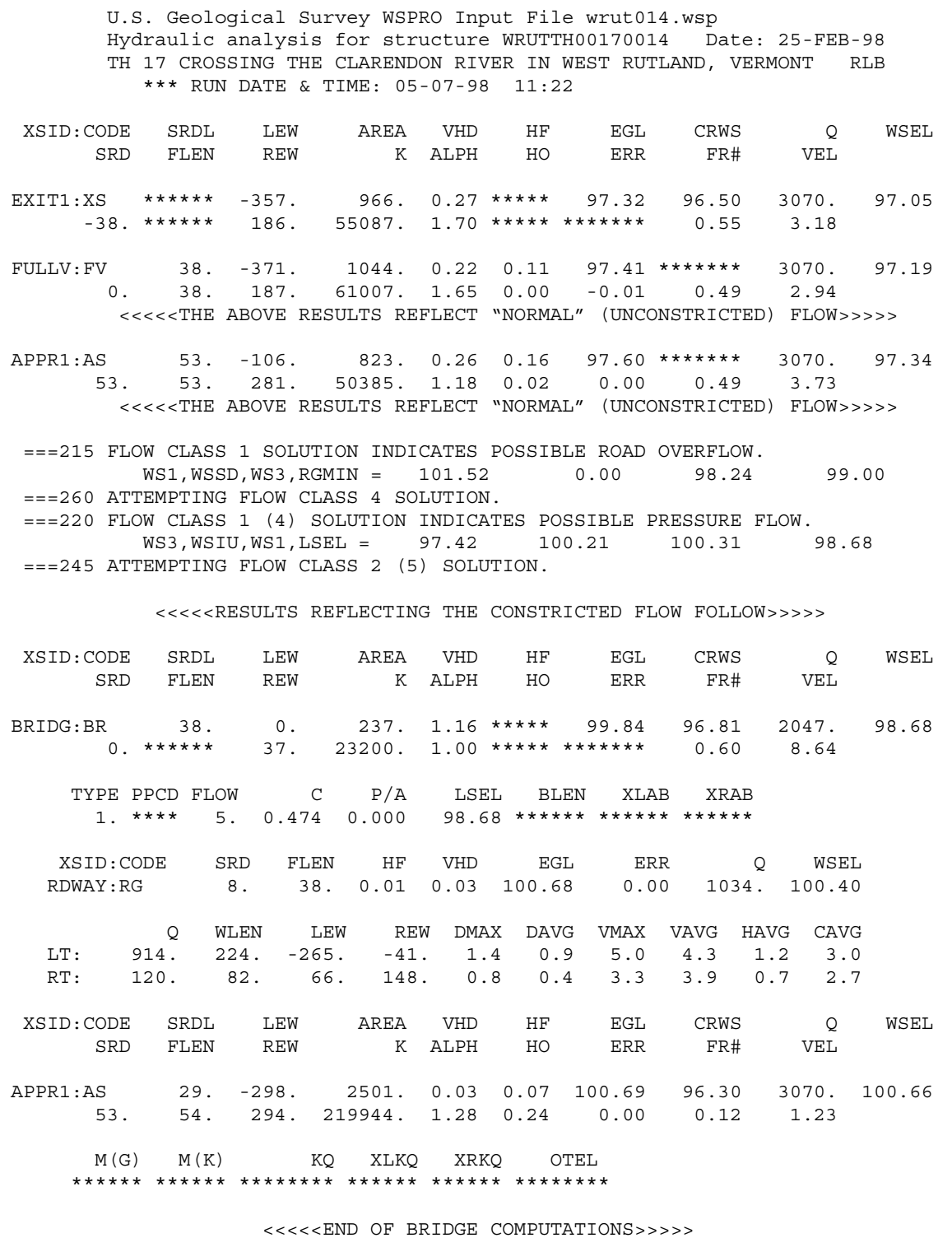

FIRST USER DEFINED TABLE.

\begin{tabular}{|c|c|c|c|c|c|c|c|c|}
\hline XSID : CODE & SRD & LEW & REW & Q & K & AREA & VEL & WSEL \\
\hline EXIT1:XS & -38 & -357 & 186. & 3070 . & 55087. & 966. & 3.18 & 97.05 \\
\hline FULLV : FV & 0 . & -371. & 187. & 3070 . & 61007. & 1044. & 2.94 & 97.19 \\
\hline BRIDG : BR & 0 . & 0. & 37. & 2047. & 23200 . & 237. & 8.64 & 98.68 \\
\hline RDWAY : RG & 8.* & $* \star * * *$ & 914. & 1034. & $\star \star \star * \star * \star * \star *$ & $\star \star \star \star \star \star *$ & 2.00 & 100.40 \\
\hline APPR I : AS & 53. & -298. & 294. & 3070 . & 219944 . & 2501. & 1.23 & 100.6 \\
\hline XSID: CODE & XLKQ & $\mathrm{XRKQ}$ & & & & & & \\
\hline
\end{tabular}

SECOND USER DEFINED TABLE.

\begin{tabular}{|c|c|c|c|c|c|c|c|c|c|}
\hline XSID : CODI & CRWS & FR\# & YMIN & YMAX & $\mathrm{HF}$ & $\mathrm{HO}$ & VHD & EGL & WSEL \\
\hline EXIT1:XS & 96.50 & 0.55 & 91.53 & 114.32 * & 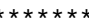 & $* \star \star \star * *$ & 0.27 & 97.32 & 97.05 \\
\hline FULLV : FV & 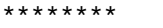 & .49 & 91.53 & 114.32 & 0.11 & 0.00 & 0.22 & 97.41 & 97.19 \\
\hline BRIDG : BR & 96.81 & 0.60 & 90.46 & $98.68 *$ & $\star \star \star * *$ & $* \star \star * *$ & 1.16 & 99.84 & 98.68 \\
\hline RDWAY : RG & 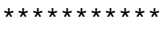 & $\star * \star * *$ & 99.00 & 127.27 & $0.01 * *$ & $* * \star * *$ & 0.03 & 100.68 & 100.40 \\
\hline APPR1:AS & 96.30 & 0.12 & 90.72 & 126.07 & 0.07 & 0.24 & 0.03 & 100.69 & 100.66 \\
\hline
\end{tabular}


WSPRO OUTPUT FILE (continued)

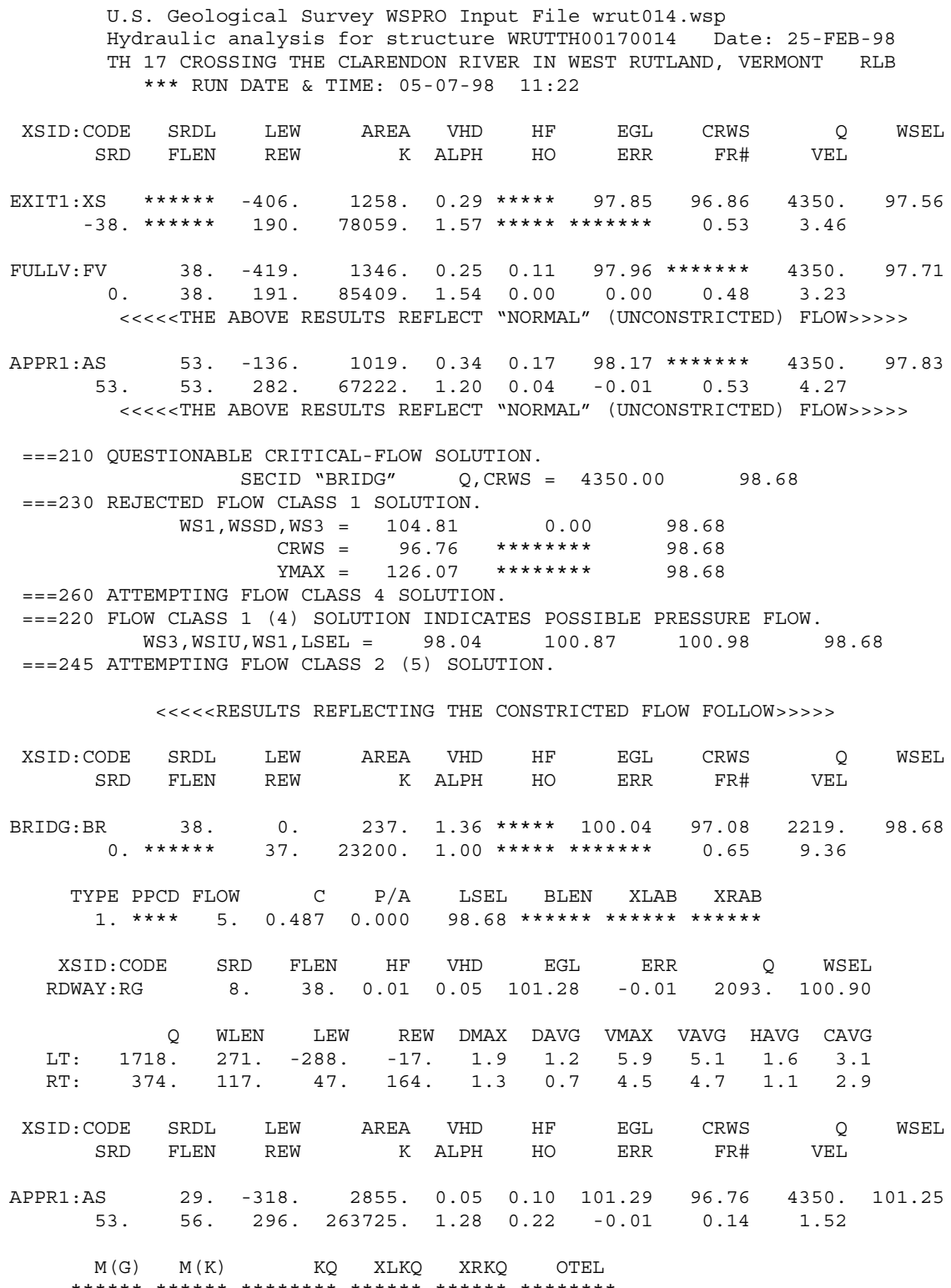

FIRST USER DEFINED TABLE.

\begin{tabular}{|c|c|c|c|c|c|c|c|c|}
\hline XSID : CODE & SRD & LEW & REW & 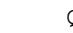 & K & AREA & VEL & WSEL \\
\hline EXIT1:XS & -38. & -406 . & 190. & 4350 & 78059. & 1258. & 3.46 & 97.56 \\
\hline FULLV : FV & 0. & -419. & 191. & 4350 & 85409. & 1346. & 3.23 & 97.71 \\
\hline BRIDG : BR & 0 . & 0 . & 37. & 2219 & 23200 . & 237. & 9.36 & 98.68 \\
\hline RDWAY : RG & 8 . & $* \star \star \star \star \star \star *$ & 1718. & 2093 & 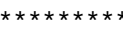 & $\star \star \star \star \star \star \star ~$ & 2.00 & 100.90 \\
\hline APPR 1 : AS & 53. & -318 & 296. & 4350 & 263725 & 2855 . & 1.52 & 101.2 \\
\hline CODE & LKQ & XRKQ & & & & & & \\
\hline
\end{tabular}

SECOND USER DEFINED TABLE.

$\begin{array}{lcccccccrr}\text { XSID : CODE } & \text { CRWS } & \text { FR\# } & \text { YMIN } & \text { YMAX } & \text { HF } & \text { HO } & \text { VHD } & \text { EGL } & \text { WSEL } \\ \text { EXIT1:XS } & 96.86 & 0.53 & 91.53 & 114.32 * * * * * * * * * * & 0.29 & 97.85 & 97.56 \\ \text { FULLV:FV } & * * * * * * * * & 0.48 & 91.53 & 114.32 & 0.11 & 0.00 & 0.25 & 97.96 & 97.71 \\ \text { BRIDG : BR } & 97.08 & 0.65 & 90.46 & 98.68 * * * * * * * * * * & 1.36 & 100.04 & 98.68 \\ \text { RDWAY : RG } & * * * * * * * * * * * * * * * & 99.00 & 127.27 & 0.01 * * * * * * & 0.05 & 101.28 & 100.90 \\ \text { APPR1:AS } & 96.76 & 0.14 & 90.72 & 126.07 & 0.10 & 0.22 & 0.05 & 101.29 & 101.25\end{array}$


WSPRO OUTPUT FILE (continued)

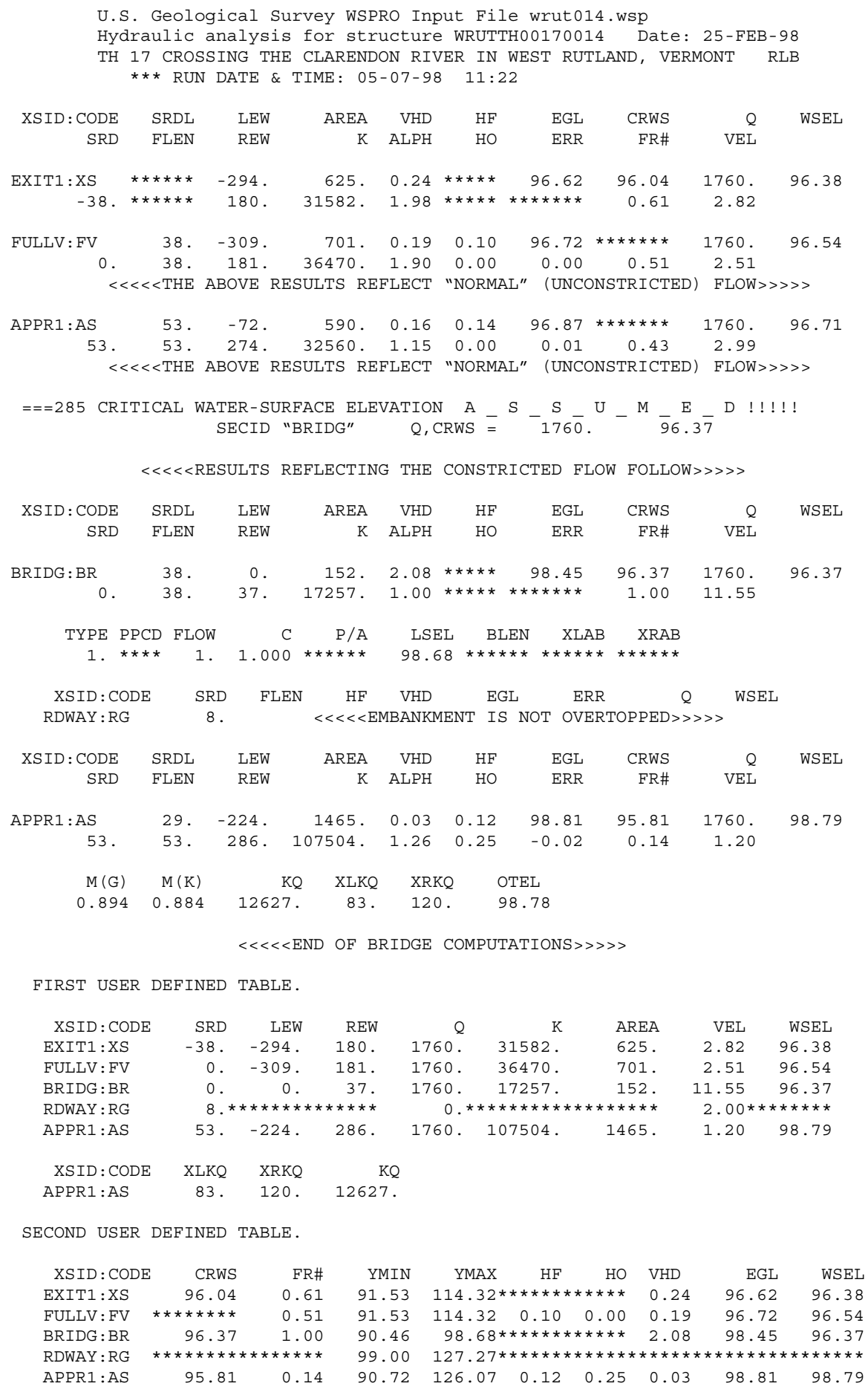




\section{APPENDIX C:}

\section{BED-MATERIAL PARTICLE-SIZE DISTRIBUTION}




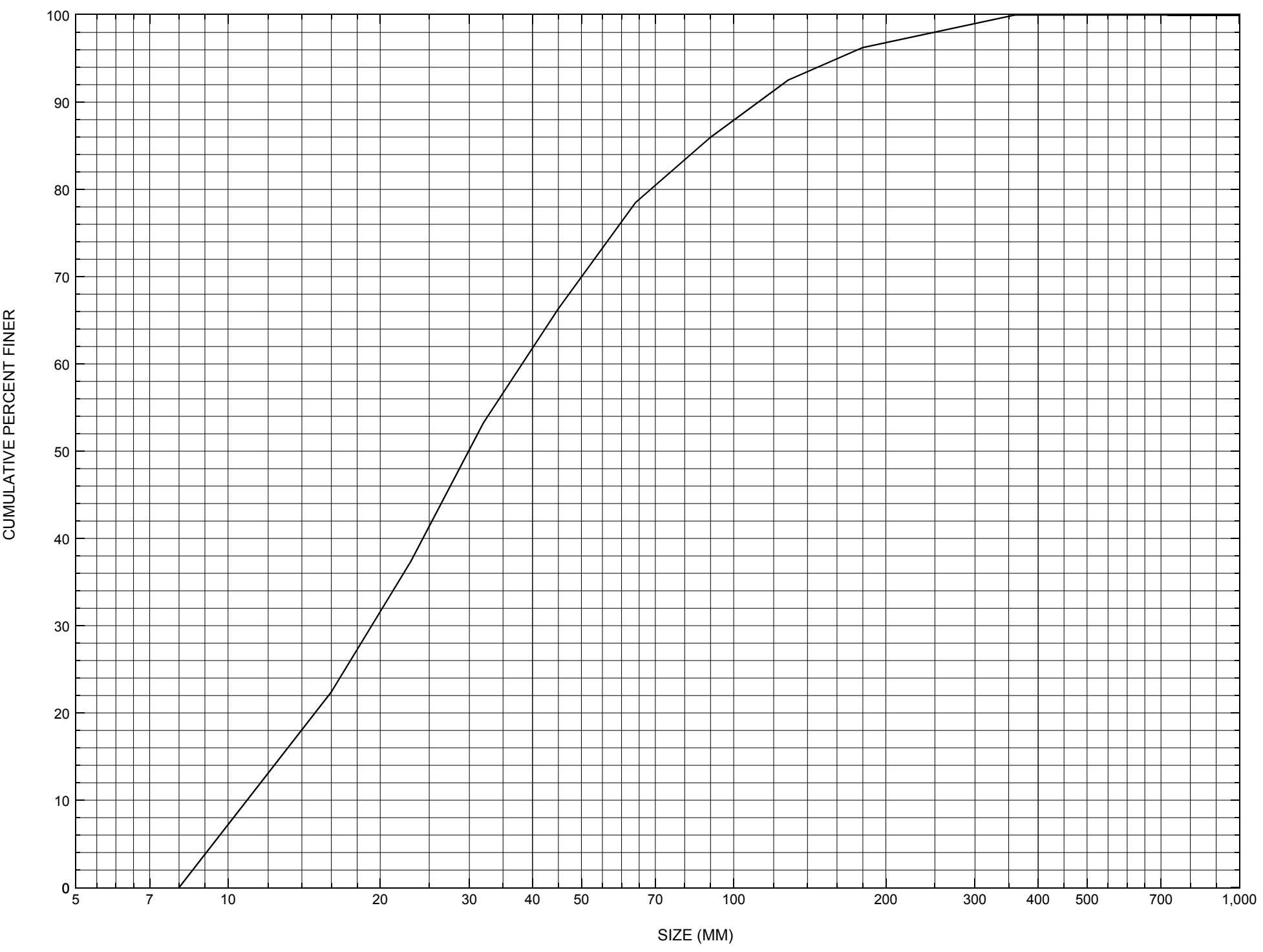

Appendix C. Bed material particle-size distribution for a pebble count in the channel approach of structure WRUTTH00170014, in West Rutland, Vermont. 


\section{APPENDIX D: \\ HISTORICAL DATA FORM}




\section{Structure Number WRUTTH00170014}

\section{General Location Descriptive}

Data collected by (First Initial, Full last name) $\mathbf{E}$. BOEHMLER

Date $(M M / D D / Y Y) \_\mathbf{0 3} / \underline{15} / \underline{95}$

Highway District Number (I - 2; nn) $\mathbf{0 3}$

Town (FIPS place code; I - 4; nnnnn) $\mathbf{8 2 3 0 0}$

Waterway (I - 6) CLARENDON RIVER

Route Number $\underline{\text { TH017 }}$

Topographic Map West Rutland

Latitude (I - 16; nnnn.n) $\mathbf{4 3 3 4 4}$
County (FIPS county code; I - 3; nnn)

Mile marker (I - 11; nnn.nnn) $\mathbf{0 0 0 0 0 0}$

Road Name (I - 7): -

Vicinity (I - 9) 0.1 MI TO JCT W VT133

Hydrologic Unit Code: $\mathbf{0 2 0 1 0 0 0 2}$

Longitude (i - 17; nnnnn.n) $\mathbf{7 3 0 2 0}$

\section{Select Federal Inventory Codes}

FHWA Structure Number $(I$ - 8) $\mathbf{1 0 1 1 2 8 0 0 1 4 1 1 2 8}$

Maintenance responsibility $(I-21 ; n n) \quad \mathbf{0 3}$

Year built (I - 27; YYYY) 1977

Average daily traffic, ADT (I - 29; nnnnnn) 000030

Year of ADT (I - 30; YY) $\mathbf{9 2}$

Opening skew to Roadway $(I-34 ; n n) \quad \mathbf{0 0}$

Operational status $(I-41 ; X) \quad \mathbf{A}$

Structure type (I - 43; nnn) $\mathbf{3 0 2}$

Approach span structure type $(I-44 ; n n n) \quad \mathbf{0 0 0}$

Number of spans (I - 45; nnn) $\mathbf{0 0 1}$

Number of approach spans (I - 46; nnnn) $\mathbf{0 0 0 0}$

Comments:

The structural inspection report of 5/11/94 indicates the structure is a steel stringer type bridge. The abutment walls are concrete. The right abutment wall has some fine cracks reported. The left abutment wall has a full-height crack and some random fine cracks noted. The upstream and downstream left wingwalls have some random areas of map cracking indicated. The inspection report mentions general scour conditions throughout the area under the bridge. The channel makes a sharp bend into the crossing just upstream of the bridge. No exposure, undermining, or settlement is reported. 


\section{Bridge Hydrologic Data}

Is there hydrologic data available? $\underline{\mathbf{Y}}$ if No, type ctrl-n $h \quad$ VTAOT Drainage area $\left(\mathrm{mi}^{2}\right)^{2}$ :

Terrain character:

Stream character \& type: -

Streambed material:

Discharge Data (cfs):

$$
\mathrm{Q}_{2.33} \frac{-}{* \mathbf{5 2 0 5}}
$$

$\mathrm{Q}_{10} \frac{* 2870}{\mathrm{Q}_{100}-}$

$$
\begin{aligned}
& Q_{25} \stackrel{3960}{-} \\
& Q_{500}-
\end{aligned}
$$

Record flood date ( $M M / D D / Y Y)$ : I Water surface elevation (ft): -

Estimated Discharge (cfs): Velocity at $\mathrm{Q} \underline{\mathbf{2 5}}$ $(\mathrm{ft} / \mathrm{s}): \mathbf{9 . 2}$ Ice conditions (Heavy, Moderate, Light) : Debris (Heavy, Moderate, Light):

The stage increases to maximum highwater elevation (Rapidly, Not rapidly):

The stream response is (Flashy, Not flashy):

Describe any significant site conditions upstream or downstream that may influence the stream's stage: -

Watershed storage area (in percent):

The watershed storage area is: - _ (1-mainly at the headwaters; 2- uniformly distributed; 3-immediatly upstream oi the site)

Water Surface Elevation Estimates for Existing Structure:

\begin{tabular}{|l|l|l|l|l|l|}
\hline Peak discharge frequency & $Q_{2.33}$ & $Q_{10}$ & $Q_{25}$ & $Q_{50}$ & $Q_{100}$ \\
Water surface elevation (ft)) & - & $\mathbf{9 7 . 2}$ & $\mathbf{9 8 . 2}$ & $\mathbf{9 8 . 9}$ & - \\
Velocity $(\mathrm{ft} / \mathrm{sec})$ & - & - & $\mathbf{9 . 2}$ & - & - \\
\hline
\end{tabular}

Long term stream bed changes: -

Is the roadway overtopped below the $\mathrm{Q}_{100}$ ? (Yes, No, Unknown): $\mathbf{U} \quad$ Frequency: Relief Elevation $(f t)$ : Discharge over roadway at $Q_{100}\left(f t^{3} / \mathrm{sec}\right)$ :

Are there other structures nearby? (Yes, No, Unknown): $\mathbf{U}$ Upstream distance (miles): Town: If No or Unknown, type ctrl-n os Highway No. : Structure No. : Year Built:

Clear span (ft): Clear Height (ft): Full Waterway $\left(f^{2}\right)$ : 
Downstream distance (miles): Town: Year Built:

Highway No. : Structure No. : Structure Type:

Clear span $(f t):$ Clear Height $(f t)$ : Full Waterway $\left(f^{2}\right)$ :

Comments:

* The hydraulics report available is not a full report. The hydrologic data in the previous section is printed on the plans but is not readily available in the hydraulic section's bridge folders.

\section{USGS Watershed Data}

Watershed Hydrographic Data

Drainage area $(D A)$

Watershed storage (ST)

Bridge site elevation

Main channel length $\mathrm{mi}^{2}$ 3 520 16.27 $10 \%$ channel length elevation $\quad \mathbf{6 0 0}$

Main channel slope $(S)$ (S) 42.47 $\mathrm{ft} / \mathrm{mi}$

Watershed Precipitation Data

Average site precipitation in Average headwater precipitation in

Maximum 2yr-24hr precipitation event $(124,2)$ in

Average seasonal snowfall (Sn) $\mathrm{ft}$ 


\section{Bridge Plan Data}

Are plans available? $\underline{Y} \quad$ If no, type ctrl-n pl Date issued for construction (MM/YYYY): 11 / 1976 Project Number DSR 0192

Minimum channel bed elevation: 91.0

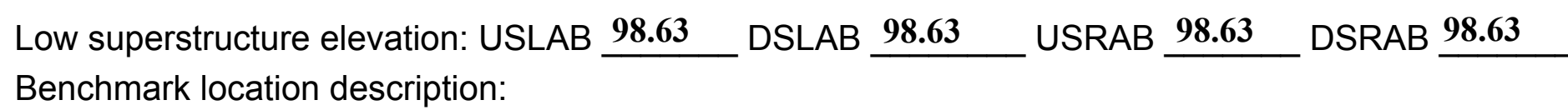

No specific benchmark information is on the plans. A couple points shown with elevations are: 1) The top streamward corner of the upstream right wingwall concrete where its slope changes from horizontal to downward, elevation 100.87; and 2) The point at the same location as in (1) but on the downstream left wingwall, the elevation is the same, 100.87 .

Reference Point (MSL, Arbitrary, Other): Arbitrary _ Datum (NAD27, NAD83, Other): Arbitrary Foundation Type: 1

If 1: Footing Thickness $\mathbf{2 . 0} \quad$ Footing bottom elevation: $\mathbf{8 7 . 0}$

If 2: Pile Type: ___ (1-Wood; 2-Steel or metal; 3-Concrete) Approximate pile driven length: -

If 3: Footing bottom elevation: -

Is boring information available? $\mathbf{N}$ If no, type ctrl-n bi Number of borings taken: -

Foundation Material Type: $\mathbf{3}$ (1-regolith, 2-bedrock, 3-unknown)

Briefly describe material at foundation bottom elevation or around piles:

$-$

Comments:

The channel bed elevation planned was to be at least 2 feet above the top of each abutment footing. 


\section{Cross-sectional Data}

Is cross-sectional data available? $\mathbf{N}$ If no, type ctrl-n xs

Source (FEMA, VTAOT, Other)? -

Comments: NO CROSS SECTION INFORMATION

\begin{tabular}{|l|l|l|l|l|l|l|l|l|l|l|l|}
\hline Station & - & - & - & - & - & - & - & - & - & - & - \\
\hline Feature & - & - & - & - & - & - & - & - & - & - & - \\
\hline $\begin{array}{l}\text { Low chord } \\
\text { elevation }\end{array}$ & - & - & - & - & - & - & - & - & - & - & - \\
\hline $\begin{array}{l}\text { Bed } \\
\text { elevation }\end{array}$ & - & - & - & - & - & - & - & - & - & - & - \\
\hline $\begin{array}{l}\text { Low chord } \\
\text { to bed }\end{array}$ & - & - & - & - & - & - & - & - & - & - & - \\
\hline Station & - & - & - & - & - & - & - & - & - & - & - \\
\hline Feature & - & - & - & - & - & - & - & - & - & - & - \\
\hline $\begin{array}{l}\text { Low chord } \\
\text { elevation }\end{array}$ & - & - & - & - & - & - & - & - & - & - & - \\
\hline $\begin{array}{l}\text { Bed } \\
\text { elevation }\end{array}$ & - & - & - & - & - & - & - & - & - & - & - \\
\hline $\begin{array}{l}\text { Low chord } \\
\text { to bed }\end{array}$ & - & - & - & - & - & - & - & - & - & - & - \\
\hline
\end{tabular}

Source (FEMA, VTAOT, Other)?

Comments: NO CROSS SECTION INFORMATION

\begin{tabular}{|l|l|l|l|l|l|l|l|l|l|l|l|}
\hline Station & - & - & - & - & - & - & - & - & - & - & - \\
\hline Feature & - & - & - & - & - & - & - & - & - & - & - \\
\hline $\begin{array}{l}\text { Low chord } \\
\text { elevation }\end{array}$ & - & - & - & - & - & - & - & - & - & - & - \\
\hline $\begin{array}{l}\text { Bed } \\
\text { elevation }\end{array}$ & - & - & - & - & - & - & - & - & - & - & - \\
\hline $\begin{array}{l}\text { Low chord } \\
\text { to bed }\end{array}$ & - & - & - & - & - & - & - & - & - & - & - \\
\hline Station & - & - & - & - & - & - & - & - & - & - & - \\
\hline Feature & - & - & - & - & - & - & - & - & - & - & - \\
\hline $\begin{array}{l}\text { Low chord } \\
\text { elevation }\end{array}$ & - & - & - & - & - & - & - & - & - & - & - \\
\hline $\begin{array}{l}\text { Bed } \\
\text { levation }\end{array}$ & - & - & - & - & - & - & - & - & - & - & - \\
\hline $\begin{array}{l}\text { Low chord } \\
\text { to bed }\end{array}$ & - & - & - & - & - & - & - & - & - & - & - \\
\hline
\end{tabular}




\section{APPENDIX E: \\ LEVEL I DATA FORM}


U. S. Geological Survey

Bridge Field Data Collection and Processing Form

Qa/Qc Check by: $\mathbf{R B}$ Date: $2 / 22 / 96$

\section{Structure Number}

\section{A. General Location Descriptive}

1. Data collected by (First Initial, Full last name) E. BOEHMLER

Date $(M M / D D / Y Y)$

2. Highway District Number $\mathbf{0 3}$

County RUTLAND (021)

Waterway (I - 6) CLARENDON RIVER

Route Number TH017

3. Descriptive comments:

The bridge is located about 0.1 mile east of the intersection of TH017 with VT 133.
Mile marker $\mathbf{0 0 0 0}$

Town WEST RUTLAND (82300)

Road Name -

Hydrologic Unit Code: $\mathbf{0 2 0 1 0 0 0 2}$

\section{B. Bridge Deck Observations}
4. Surface cover... LBUS 6
RBUS 4
LBDS 4
RBDS 4
Overall 4

(2b us, ds,lb,rb: 1- Urban; 2- Suburban; 3- Row crops; 4- Pasture; 5- Shrub- and brushland; 6- Forest; 7- Wetland)
5. Ambient water surface... US 1
UB 1
DS 1
(1- pool; 2- riffle)

6. Bridge structure type 1 (1- single span; 2- multiple span; 3- single arch; 4- multiple arch; 5-cylindrical culvert; 6- box culvert; or 7- other)
7. Bridge length 41
(feet)
Span length $\mathbf{3 7}$
(feet)
Bridge width 14.7 (feet)

\section{Road approach to bridge:}
8. LB 1 RB 1
( 0 even, 1- lower, 2- higher)
9. LB 2
RB $\underline{2}$
(1- Paved, 2- Not paved)

10. Embankment slope (run / rise in feet / foot)
US left
3.2:1
US right
2.2:1

\begin{tabular}{|c|c|c|c|c|}
\hline & \multicolumn{2}{|c|}{ Protection } & \multirow{2}{*}{ 13.Erosion } & \multirow{2}{*}{ 14.Severity } \\
\hline & 11.Type & 12.Cond. & & \\
\hline LBUS & 2 & 1 & 1 & 2 \\
\hline RBUS & 0 & - & 0 & $\mathbf{0}$ \\
\hline BDS & $\mathbf{0}$ & - & $\mathbf{0}$ & $\mathbf{0}$ \\
\hline LBDS & $\mathbf{0}$ & - & $\mathbf{0}$ & $\mathbf{0}$ \\
\hline
\end{tabular}

Bank protection types: 0- none; 1- < 12 inches;

2- < 36 inches; 3- < 48 inches;

4- < 60 inches; 5- wall / artificial levee

Bank protection conditions: 1- good; 2- slumped;

3- eroded; 4- failed

Erosion: 0 - none; 1- channel erosion; 2 -

road wash; 3- both; 4- other

Erosion Severity: 0 - none; 1- slight; 2- moderate; 3- severe

\section{Channel approach to bridge (BF):}

15. Angle of approach: $\mathbf{2 0}$

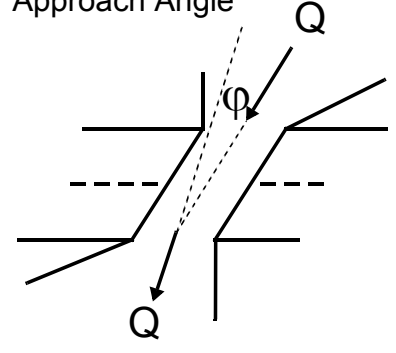

17. Channel impact zone 1:

Where? LB $(L B, R B)$

Range? 65 feet $\underline{\text { US }}$

Channel impact zone 2:

Where? RB $(L B, R B)$

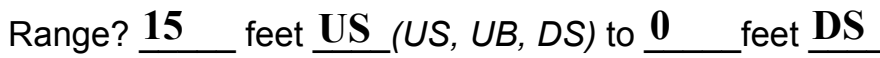

Impact Severity: 0- none to very slight; 1- Slight; 2- Moderate; 3- Severe
16. Bridge skew: $\mathbf{0}$ Bridge Skew Angle

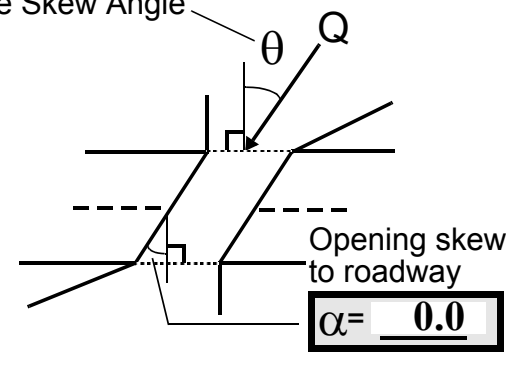

\section{Exist? $\mathbf{Y}(Y$ or $N)$}

Severity 3

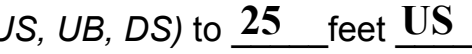

Exist? $\mathbf{Y}(Y$ or $N)$

Severity $\underline{2}$ 
18. Bridge Type: 4

1a- Vertical abutments with wingwalls

1 b- Vertical abutments without wingwalls

2- Vertical abutments and wingwalls, sloping embankment Wingwalls parallel to abut. face

3- Spill through abutments

4- Sloping embankment, vertical wingwalls and abutments

Wingwall angle less than $90^{\circ}$.

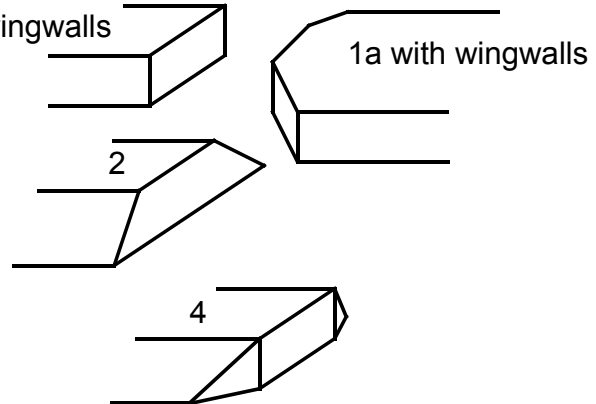

19. Bridge Deck Comments (surface cover variations, measured bridge and span lengths, bridge type variations, approach overflow width, etc.)

7. Bridge dimension values are from VT AOT files. Measured bridge dimensions are: bridge length 41 feet, span length 37 feet, and bridge width 14.5 feet.

4. The surface cover US on the left bank is forest for at least 2 bridge lengths, and pasture beyond the trees. The US right bank is pasture except for a narrow (20 feet maximum) strip of trees between the bank and the pasture. Both the left and right banks DS are pasture except for a few trees on the bank edge. There is a small wetland area on the DS right bank.

\section{Upstream Channel Assessment}

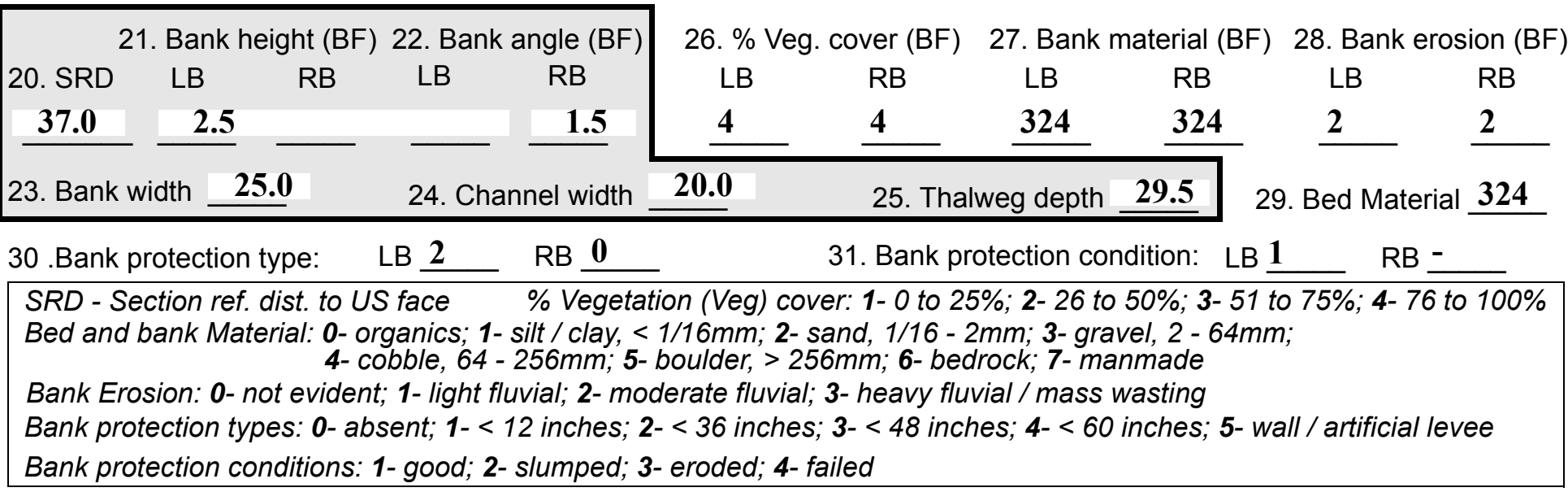

32. Comments (bank material variation, minor inflows, protection extent, etc.):

The left bank is protected from 0 feet US to about 65 feet US. The channel US is in a state of transition. A point bar is located on the left bank side and this is also an impact zone as a channel is developing across the bankward part of the bar. During high flows, water occupies this channel and impacts the left road approach embankment. The embankment is protected and is also the left bank to about 65 feet US. At 65 feet upstream the channel makes a 70 degree bend to the right toward the bridge, then another bend left just US of the bridge opening. This second bend is about 45 degrees such that flow approaches the bridge skewed to the abutment wall. The US channel has a series of pools and riffles around multiple point bars and meanders toward the bridge. 
36. Point bar extent: $\underline{\mathbf{1 1 0}}$ feet $\underline{\mathbf{U S}}$ (US, UB) to $\underline{\mathbf{5 0}}$ feet $\underline{\mathbf{U S}}$ (US, UB, DS) positioned $\underline{\mathbf{0}} \%$ LB to $\underline{\mathbf{6 0}} \%$ RB

37. Material: 34

38. Point or side bar comments (Circle Point or Side; Note additional bars, material variation, status, etc.):

The point bar is unvegetated where an overflow channel is eroding across the left bank side, and vegetated near mid-channel. The vegetated portion comprises about $25 \%$ of the bar area. An additional point bar is developing on the right bank from 55 feet US to 30 feet US. Mid-bar is 40 feet US where it is about 10 feet wide. It is composed of fine gravel and sand and is positioned $80 \% \mathrm{LB}$ to $100 \% \mathrm{RB}$.
39. Is a cut-bank present? $\mathbf{Y}$
( $Y$ or if $N$ type $c$ trl-n $c b)$
40. Where? RB
(LB or RB)

41. Mid-bank distance: $\mathbf{8 0}$

42. Cut bank extent: 95

feet $\underline{\text { US }}$

(US, UB) to $\underline{55}$ feet $\underline{\mathbf{U S}}$ (US, UB, DS)

43. Bank damage: 1

(1- eroded and/or creep; 2- slip failure; 3- block failure)

44. Cut bank comments (eg. additional cut banks, protection condition, etc.):

As the channel erodes behind the point bar on the left bank, this cut bank will be less impacted.

45. Is channel scour present? $\mathbf{Y}$ ( $Y$ or if $N$ type ctrl-n cs)

47. Scour dimensions: Length $\mathbf{9 8}$ Width 19 Depth : 2

$P$

46. Mid-scour distance: $\underline{0}$

48. Scour comments (eg. additional scour areas, local scouring process, etc.):

The scour depth varies from .5 foot to 2 feet. The scour is along the channel thalweg US beginning where the thalweg impacts the stone fill on the US left wingwall and continues through the bridge along the stone fill on both abutments and along the toe of the stone fill on the DS right wingwall.
49. Are there major confluences? Y
( $Y$ or if $N$ type ctrl-n $m c)$
51. Confluence 1: Distance 105
52. Enters on $\mathbf{L B}$
( $L B$ or $R B)$
Confluence 2: Distance -
Enters on - (LB or $R B)$

54. Confluence comments (eg. confluence name):

50. How many? 1

53. Type 2 (1- perennial; 2- ephemeral)

Type (1- perennial; 2- ephemeral)

-

\section{Under Bridge Channel Assessment}

55. Channel restraint (BF)? LB 2

\begin{tabular}{|ccccc}
\hline \multicolumn{2}{|c}{ 56. Height (BF) } & \multicolumn{3}{c}{57 Angle (BF) } \\
LB & RB & LB & RB \\
$\mathbf{2 1 . 0}$ & & & $\mathbf{2 . 5}$ & \\
\hline
\end{tabular}
(1- natural bank; 2- abutment; 3- artificial levee)

58. Bank width (BF) -

59. Channel width -

\begin{tabular}{lc} 
61. Material (BF) \\
LB & RB \\
$\mathbf{2}$ & $\mathbf{7}$ \\
\hline
\end{tabular}

clay, $<1 / 16 m+$ r

Bed and bank Material: 0- organics; 1- silt / clay, < 1/16mm; 2- sand, 1/16 - 2mm; 3- gravel, 2 - 64mm; 4- cobble, 64 - 256mm; 5- boulder, > 256mm; 6- bedrock; 7- manmade

Bank Erosion: 0- not evident; 1- light fluvial; 2- moderate fluvial; 3- heavy fluvial / mass wasting

64. Comments (bank material variation, minor inflows, protection extent, etc.):

324 
65. Debris and Ice Is there debris accumulation?

$(Y$ or $N)$ 66. Where? $\underline{Y}$

(1- Upstream; 2- At bridge; 3- Both)

67. Debris Potential 1 (1- Low; 2- Moderate; 3- High)

68. Capture Efficiency 3 (1-Low; 2- Moderate; 3- High)

69. Is there evidence of ice build-up? 2 (Y or $N)$

Ice Blockage Potential $\underline{\mathbf{N}}$

(1-Low; 2- Moderate; 3- High)

70. Debris and Ice Comments:

2

The channel meanders and the banks are well vegetated with trees. Point bars at the bends are likely to trap debris and ice US and DS of the bridge.

\begin{tabular}{|l|c|c|c|c|c|c|c|c|}
\hline Abutments & $\begin{array}{c}\text { 71. Attack } \\
\angle \text { (BF) }\end{array}$ & $\begin{array}{c}\text { 72. Slope } \angle \\
\text { (Qmax) }\end{array}$ & $\begin{array}{c}\text { 73. Toe } \\
\text { loc. (BF) }\end{array}$ & $\begin{array}{c}\text { 74. Scour } \\
\text { Condition }\end{array}$ & $\begin{array}{c}75 . \text { Scour } \\
\text { depth }\end{array}$ & $\begin{array}{c}\text { 76. Exposure } \\
\text { depth }\end{array}$ & 77. Material & 78. Length \\
\hline LABUT & & - & $\mathbf{9 0}$ & $\mathbf{2}$ & $\mathbf{1}$ & $\mathbf{2}$ & $\mathbf{0}$ & $\mathbf{9 0 . 0}$ \\
\hline RABUT & $\mathbf{1}$ & $\mathbf{1 5}$ & $\mathbf{9 0}$ & & & $\mathbf{2}$ & $\mathbf{1}$ & $\mathbf{3 7 . 0}$ \\
\hline
\end{tabular}

Pushed: $L B$ or RB

Toe Location (Loc.): 0- even, 1- set back, 2- protrudes

Scour cond.: 0- not evident; 1- evident (comment); 2- footing exposed; 3-undermined footing; 4- piling exposed; 5- settled; 6- failed

Materials: 1- Concrete; 2- Stone masonry or drywall; 3- steel or metal; 4- wood

79. Abutment comments (eg. undermined penetration, unusual scour processes, debris, etc.):

1.5

$\mathbf{0}$

1

The scour hole runs along the toe of the stone fill visible at the US end of the left abutment and along the stone fill on the right abutment its entire length. The stone fill on the US end of the left abutment protrudes into the channel 12 feet from the wall. The stone fill on the right abutment protrudes into the channel 8 feet from the wall.

80. Wingwalls:

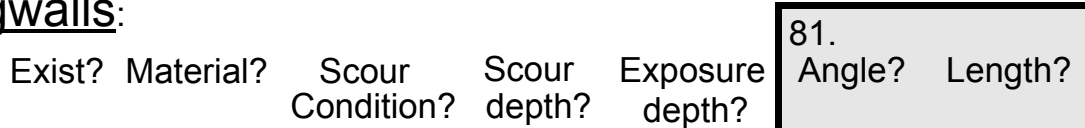

USLWW:

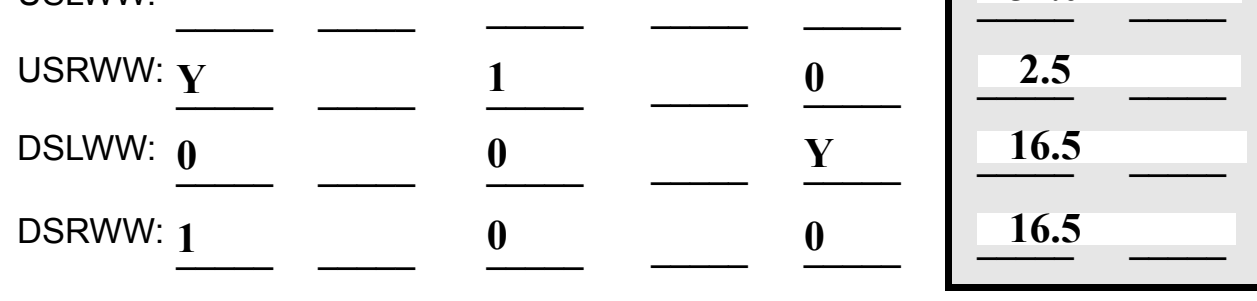

Wingwall materials: 1- Concrete; 2- Stone masonry or drywall; 3- steel or metal; 4- wood

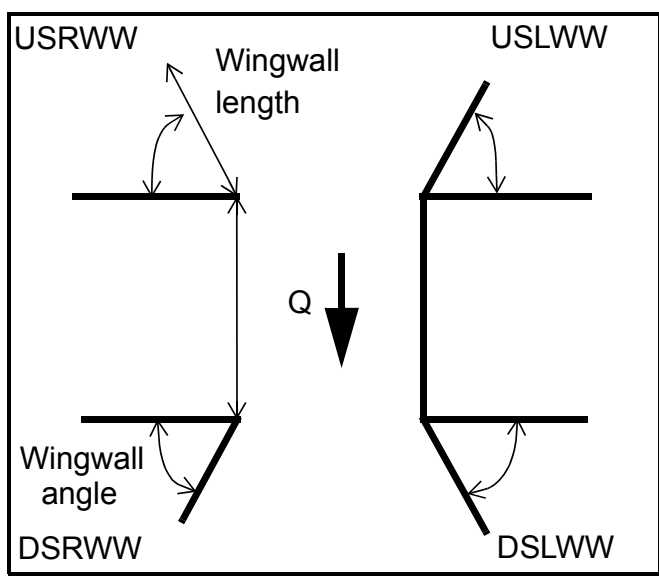

82. Bank / Bridge Protection:

\begin{tabular}{|l|l|l|l|l|l|l|l|c|}
\hline Location & USLWW & USRWW & LABUT & RABUT & LB & RB & DSLWW & DSRWW \\
\hline Type & $\mathbf{0}$ & $\mathbf{0}$ & $\mathbf{Y}$ & $\mathbf{0}$ & $\mathbf{1}$ & $\mathbf{2}$ & $\mathbf{1}$ & $\mathbf{1}$ \\
\hline Condition & $\mathbf{Y}$ & $\mathbf{0}$ & $\mathbf{1}$ & $\mathbf{0}$ & $\mathbf{1}$ & $\mathbf{1}$ & $\mathbf{2}$ & $\mathbf{1}$ \\
\hline Extent & $\mathbf{1}$ & $\mathbf{0}$ & $\mathbf{0}$ & $\mathbf{2}$ & $\mathbf{2}$ & $\mathbf{2}$ & $\mathbf{2}$ & - \\
\hline
\end{tabular}

Bank / Bridge protection types: 0- absent; 1- < 12 inches; 2- < 36 inches; 3- < 48 inches; 4- < 60 inches; 
83. Wingwall and protection comments (eg. undermined penetration, unusual scour processes, etc.):

-
-
-
-
-
1
1
1
2
1
1

Piers:

84. Are there piers? Th (Y or if N type ctrl-n pr)

\begin{tabular}{|l|l|l|l|l|l|l|l|}
\hline \multirow{2}{*}{$\begin{array}{l}85 . \\
\text { Pier no. }\end{array}$} & \multicolumn{3}{|c|}{ width (w) feet } & \multicolumn{3}{c|}{ elevation (e) feet } \\
\cline { 2 - 8 } & w1 & w2 & w3 & e@w1 & e@w2 & e@w3 \\
\hline Pier 1 & & & & $\mathbf{2 0 . 0}$ & $\mathbf{1 8 . 0}$ & $\mathbf{6 0 . 0}$ \\
\hline Pier 2 & & & & $\mathbf{1 0 . 0}$ & $\mathbf{4 5 . 0}$ & $\mathbf{1 5 . 0}$ \\
\hline Pier 3 & & & - & $\mathbf{6 0 . 0}$ & $\mathbf{1 0 . 0}$ & - \\
\hline Pier 4 & - & - & - & - & - & - \\
Nyyyy
\end{tabular}

\begin{tabular}{|l|l|l|l|l|}
\hline Level 1 Pier Descr. & \multicolumn{1}{|c|}{1} & \multicolumn{1}{|c|}{2} & \multicolumn{1}{|c|}{3} & \multicolumn{1}{|c|}{4} \\
\hline 86. Location (BF) & e US & fill is & ment & chan- \\
\hline 87. Type & left & only & but & nel \\
\hline 88. Material & wing & visi- & is & fill \\
\hline 89. Shape & wall & ble & prob & (san \\
\hline 90. Inclined? & has & at & ably & d, \\
\hline 91. Attack $\angle$ (BF) & the & the & cov- & silt, \\
\hline 92. Pushed & most & US & ered & and \\
\hline 93. Length (feet) & - & - & - & - \\
\hline 94. \# of piles & pro- & end & on & fine \\
\hline 95. Cross-members & tec- & of & the & grav \\
\hline 96. Scour Condition & tion. & the & DS & el) as \\
\hline 97. Scour depth & The & left & end & a \\
\hline 98. Exposure depth & stone & abut & by & point \\
\hline
\end{tabular}

LFP, LTB, LB, MCL, MCM, MCR, RB, RTB, RFP

1- Solid pier, 2- column, 3- bent

1-Wood; 2- concrete; 3- metal; 4- stone

1- Round; 2- Square; 3- Pointed

Y-yes; $N-$ no

$L B$ or $R B$

0- none; 1- laterals; 2- diagonals; 3- both

0- not evident; 1- evident (comment);

2- footing exposed; 3- piling exposed;

4- undermined footing; 5 - settled; 6 - failed 
99. Pier comments (eg. undermined penetration, protection and protection extent, unusual scour processes, etc.):

bar begins on the left bank here. The DS left wingwall protection is mainly road fill. The US right wingwall protection is slumping in the area of the impact.

$\mathbf{N}$

100.

\section{E. Downstream Channel Assessment}

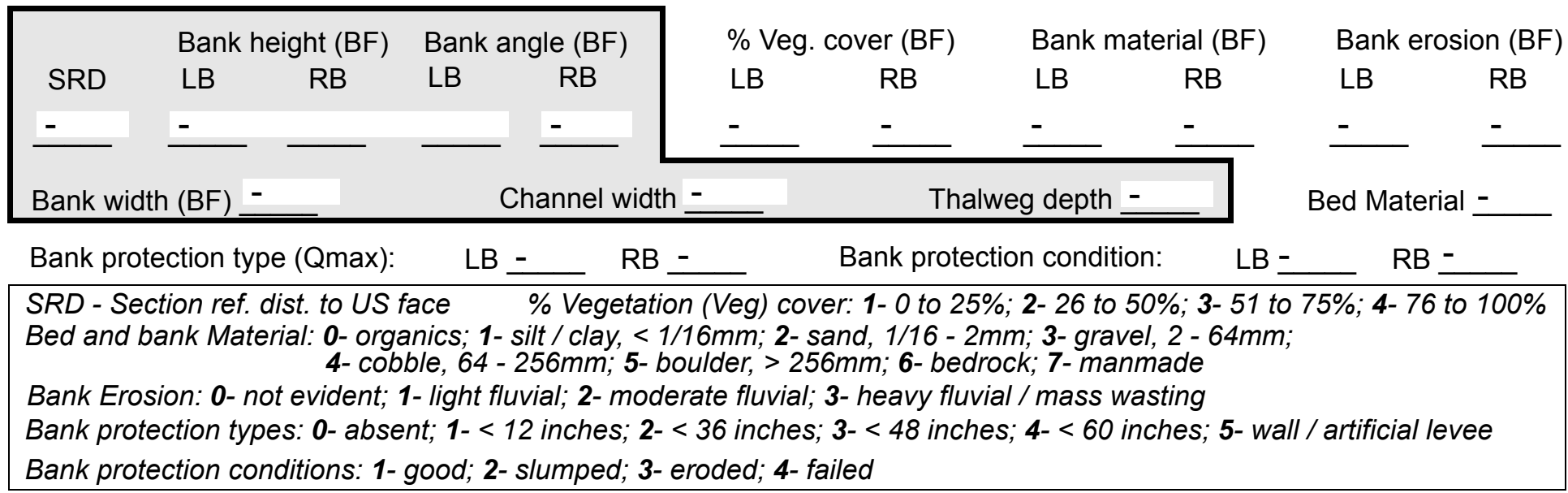

Comments (eg. bank material variation, minor inflows, protection extent, etc.):

$-$

$-$

-

-

-

-

-

-

-

-

-

-

-

-

101. Is a drop structure present? _ ( $Y$ or $N$, if $N$ type ctrl-n ds) 102. Distance: ___ feet
103. Drop: - feet
104. Structure material: -
(1- steel sheet pile; 2- wood pile; 3- concrete; 4- other)

105. Drop structure comments (eg. downstream scour depth):

$-$

-

-

- 
106. Point/Side bar present? (Y or $N$. if $N$ type ctrl-n pb)Mid-bar distance:

Mid-bar width: -

Point bar extent: feet -

(US, UB, DS) to feet (US, UB, DS) positioned $\%$ LB to $\% \mathrm{RB}$

Material:

Point or side bar comments (Circle Point or Side; note additional bars, material variation, status, etc.):

$-$

$-$

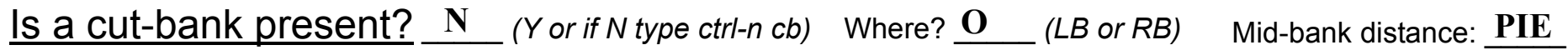
Cut bank extent: $\underline{\mathbf{R S}}$ feet (US, UB, DS) to feet (US, UB, DS)

Bank damage: (1- eroded and/or creep; 2- slip failure; 3- block failure)

Cut bank comments (eg. additional cut banks, protection condition, etc.):

Is channel scour present? ( $Y$ or if $N$ type ctrl-n cs) Width 324 Depth: 324 Scour dimensions: Length 1

Scour comments (eg. additional scour areas, local scouring process, etc.): 324

0

$\mathbf{0}$

Are there major confluences? Confluence 1: Distance DS ( $Y$ or if $N$ type ctrl-n $m c)$

Confluence 2: Distance mean Enters on cha $(L B$ or $R B)$ Enters on ders (LB or $R B)$

Mid-scour distance: 4

Positioned 1 \%LB to 2 $\%$ RB Confluence comments (eg. confluence name):

point bars and cut banks alternating sides. The channel DS continues to bend left from where the left bend began US. The banks are unprotected.

\section{F. Geomorphic Channel Assessment}

107. Stage of reach evolution

1- Constructed

2- Stable

3- Aggraded

4- Degraded

5- Laterally unstable

6- Vertically and laterally unstable 
108. Evolution comments (Channel evolution not considering bridge effects; See HEC-20, Figure 1 for geomorphic descriptors): 


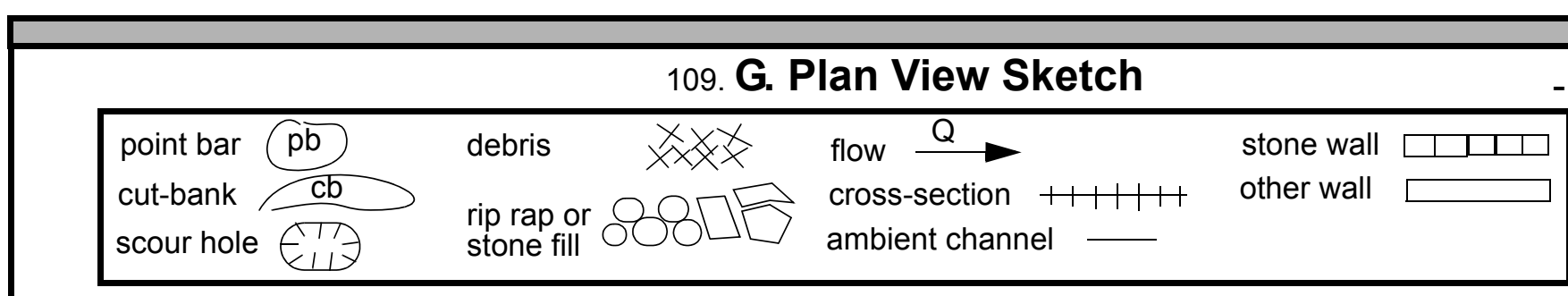


APPENDIX F:

SCOUR COMPUTATIONS 


\begin{tabular}{|c|c|c|c|}
\hline Structure Number: WRUTTH00170014 & & Town: & WEST RUTLAND \\
\hline Road Number: $\quad$ TH 17 & & County: & RUTLAND \\
\hline Stream: CLARENDON RIVER & & & \\
\hline Initials RLB & Checked: & $\mathrm{ECW}$ & \\
\hline Analysis of contraction scour, li & bed or c & Lear wa & \\
\hline $\begin{array}{l}\text { Critical Velocity of Bed Material } \\
\text { VC=11.21*y } 1 \wedge 0.1667 * \mathrm{D} 50^{\wedge} 0.33 \text { with } \mathrm{S}\end{array}$ & $\begin{array}{l}\text { converted } \\
=2.65\end{array}$ & to Engl & sh units) \\
\hline (Richardson and Davis, 1995, p. 28 & eq. 16) & & \\
\hline Approach Section & & & \\
\hline Characteristic & $100 \mathrm{yr}$ & $500 \mathrm{yr}$ & other $Q$ \\
\hline Total discharge, cfs & 3320 & 4600 & 1910 \\
\hline Main Channel Area, ft2 & 233 & 251 & 178 \\
\hline Left overbank area, ft2 & 791 & 973 & 300 \\
\hline Right overbank area, ft2 & 1476 & 1633 & 989 \\
\hline Top width main channel, ft & 29 & 29 & 29 \\
\hline Top width L overbank, ft & 298 & 318 & 224 \\
\hline Top width $\mathrm{R}$ overbank, ft & 264 & 267 & 257 \\
\hline D50 of channel, ft & 0.0981 & 0.0981 & 0.0981 \\
\hline D50 left overbank, ft & -- & -- & -- \\
\hline D50 right overbank, ft & -- & -- & -- \\
\hline $\mathrm{Y}_{1}$, average depth, $\mathrm{MC}$, ft & 8.0 & 8.7 & 6.1 \\
\hline y1, average depth, LOB, ft & 2.7 & 3.1 & 1.3 \\
\hline y1, average depth, ROB, ft & 5.6 & 6.1 & 3.8 \\
\hline Total conveyance, approach & 219991 & 263895 & 107696 \\
\hline Conveyance, main channel & 28616 & 32250 & 18284 \\
\hline Conveyance, LOB & 37692 & 50936 & 9028 \\
\hline Conveyance, ROB & 153682 & 180709 & 80384 \\
\hline Percent discrepancy, conveyance & 0.0005 & 0.0000 & 0.0000 \\
\hline Qm, discharge, MC, cfs & 431.9 & 562.2 & 324.3 \\
\hline Q1, discharge, LOB, cfs & 568.8 & 887.9 & 160.1 \\
\hline Qr, discharge, ROB, cfs & 2319.3 & 3150.0 & 1425.6 \\
\hline Vm, mean velocity $\mathrm{MC}$, ft/s & 1.9 & 2.2 & 1.8 \\
\hline Vl, mean velocity, LOB, ft/s & 0.7 & 0.9 & 0.5 \\
\hline Vr, mean velocity, ROB, ft/s & 1.6 & 1.9 & 1.4 \\
\hline Vc-m, crit. velocity, MC, ft/s & 7.3 & 7.4 & 7.0 \\
\hline Vc-l, crit. velocity, LOB, ft/s & $\mathrm{ERR}$ & ERR & $\mathrm{ERR}$ \\
\hline Vc-r, crit. velocity, ROB, ft/s & ERR & ERR & ERR \\
\hline Results & & & \\
\hline Live-bed(1) or Clear-Water(0) Cont & action Sc & our? & \\
\hline Main Channel & 0 & 0 & 0 \\
\hline Left Overbank & $\mathrm{N} / \mathrm{A}$ & $\mathrm{N} / \mathrm{A}$ & $\mathrm{N} / \mathrm{A}$ \\
\hline Right Overbank & $\mathrm{N} / \mathrm{A}$ & $\mathrm{N} / \mathrm{A}$ & $\mathrm{N} / \mathrm{A}$ \\
\hline
\end{tabular}


Clear Water Contraction Scour in MAIN CHANNEL

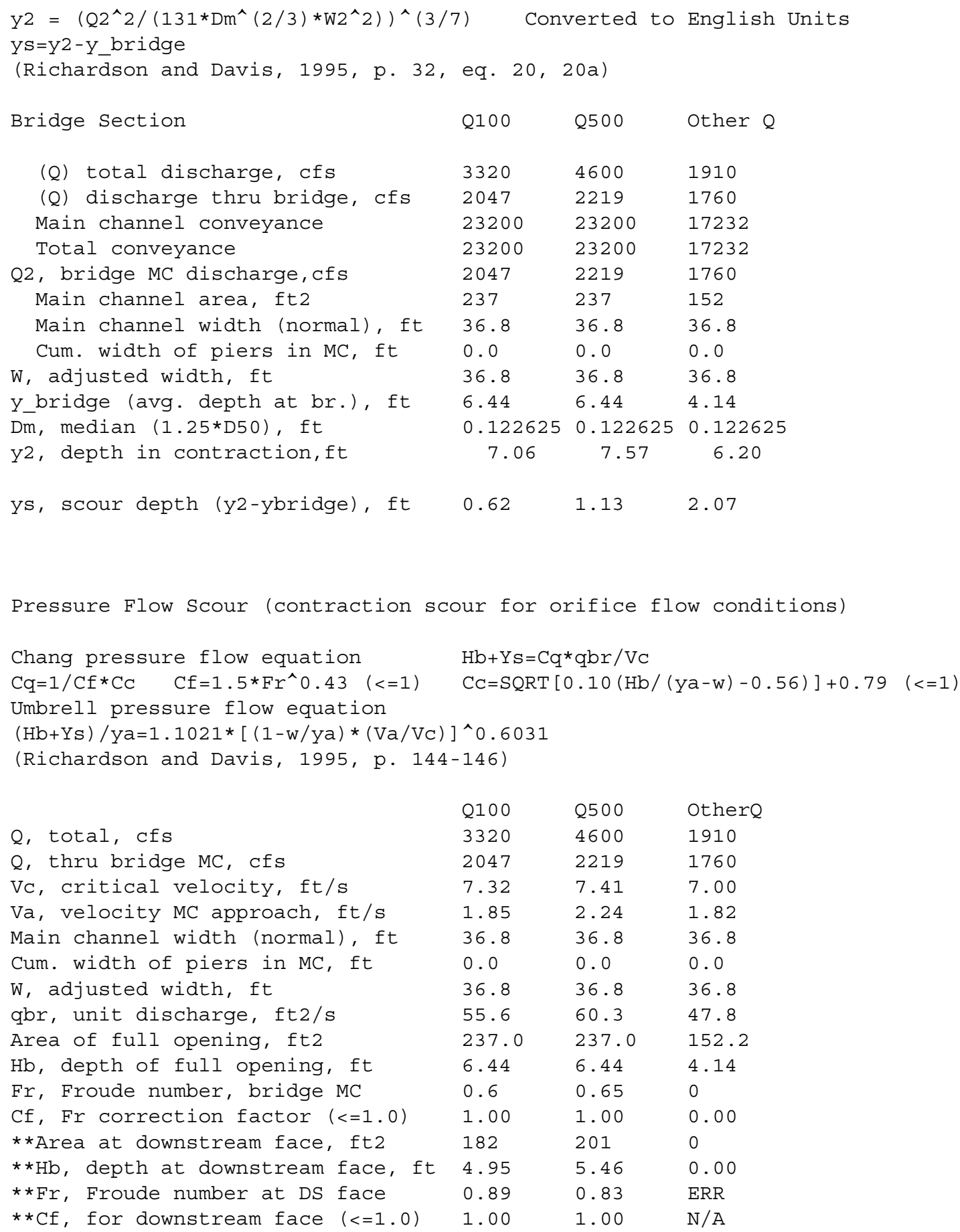




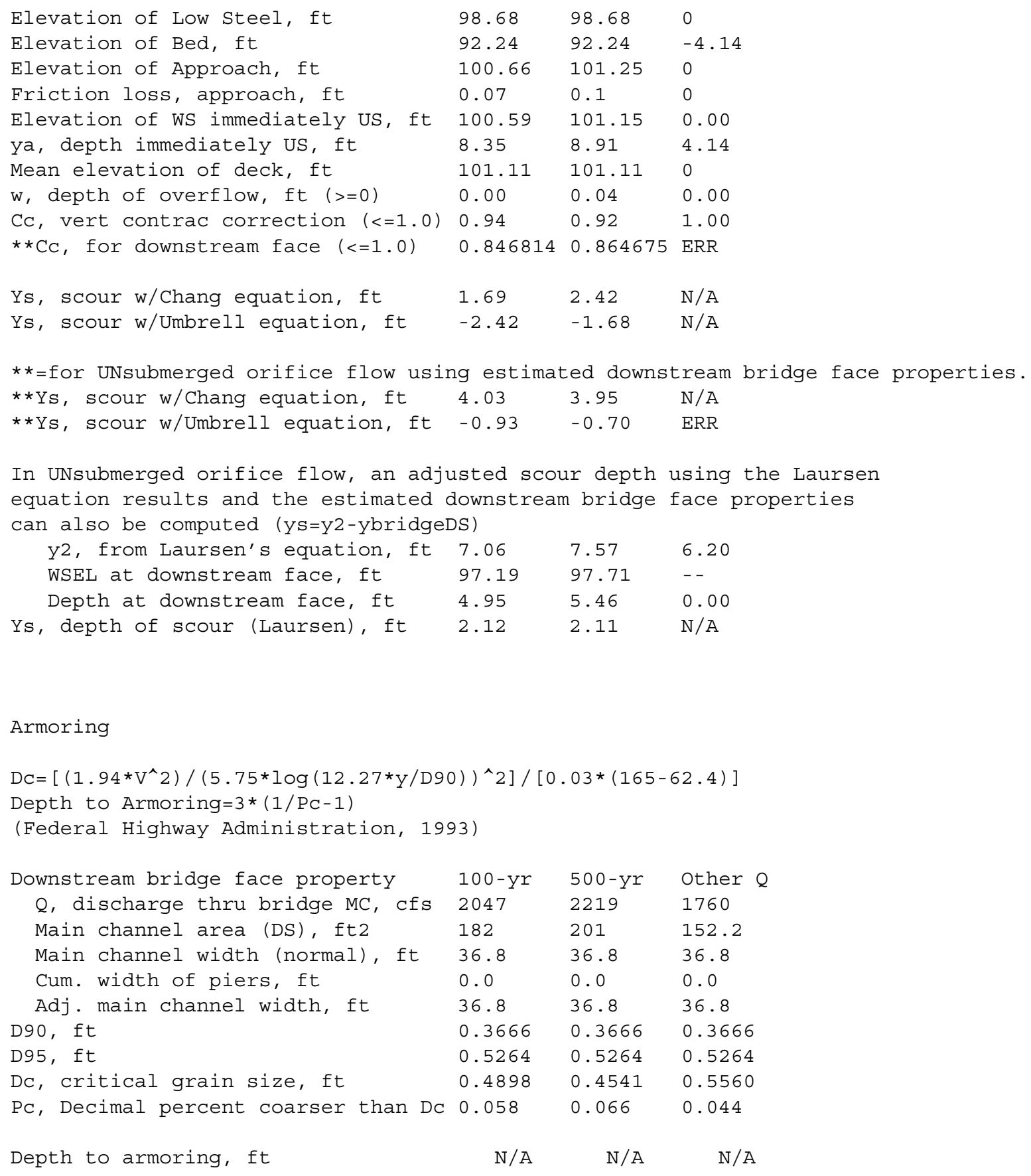

Abutment Scour

Froehlich's Abutment Scour

$\mathrm{Ys} / \mathrm{Y} 1=2.27 * \mathrm{~K} 1 * \mathrm{~K} 2 *\left(\mathrm{a}^{\prime} / \mathrm{Y} 1\right)^{\wedge} 0.43 * \mathrm{Fr} 1^{\wedge} 0.61+1$

(Richardson and Davis, 1995, p. 48, eq. 28)

Characteristic

(Qt), total discharge, cfs $\quad 3320 \quad 4600 \quad 1910 \quad 3320 \quad 4600 \quad 1910$

Left Abutment $100 \mathrm{yr} Q 500 \mathrm{yr} Q$ Other Q $100 \mathrm{yr}$ Q $500 \mathrm{yr} Q$ Other Q 


\begin{tabular}{|c|c|c|c|c|c|c|}
\hline $\mathrm{a}^{\prime}$, abut.length blocking flow, ft & 297.8 & 317.7 & 224.4 & 256.9 & 259.3 & 249.5 \\
\hline Ae, area of blocked flow ft 2 & 608.87 & 655.9 & 311.92 & 1407.44 & 1516.54 & 959.75 \\
\hline $\begin{array}{l}\text { Qe, discharge blocked abut., cfs } \\
\text { (If using Qtotal_overbank to obta }\end{array}$ & in $\begin{array}{c}-- \\
\mathrm{Ve}\end{array}$ & eave Qe & $\begin{array}{c}178.29 \\
\text { blank and }\end{array}$ & $\begin{array}{c}-- \\
\text { enter } \text { Ve }\end{array}$ & and Fr ma & $\begin{array}{l}1382.65 \\
\text { nually) }\end{array}$ \\
\hline Ve, $(\mathrm{Qe} / \mathrm{Ae}), \mathrm{ft} / \mathrm{s}$ & 0.76 & 0.92 & 0.57 & 1.57 & 1.93 & 1.44 \\
\hline ya, depth of $f / p$ flow, ft & 2.04 & 2.06 & 1.39 & 5.48 & 5.85 & 3.85 \\
\hline -Coeff., K1, for abut. type (1.0, & verti.; & $0.82, \mathrm{ve}$ & rti. w/ & ngwall; & .55, spil & Ithru) \\
\hline $\mathrm{K} 1$ & 0.82 & 0.82 & 0.82 & 0.82 & 0.82 & 0.82 \\
\hline --Angle (theta) of embankment $(<90$ & if abut & points & $\mathrm{DS} ;>90$ if & abut. po & ints US) & \\
\hline theta & 90 & 90 & 90 & 90 & 90 & 90 \\
\hline $\mathrm{K} 2$ & 1.00 & 1.00 & 1.00 & 1.00 & 1.00 & 1.00 \\
\hline Fr, froude number $\mathrm{f} / \mathrm{p}$ flow & 0.081 & 0.092 & 0.085 & 0.117 & 0.137 & 0.129 \\
\hline IS, SC & 9.04 & 9.88 & 6.53 & 19.89 & 22.38 & 16.22 \\
\hline
\end{tabular}

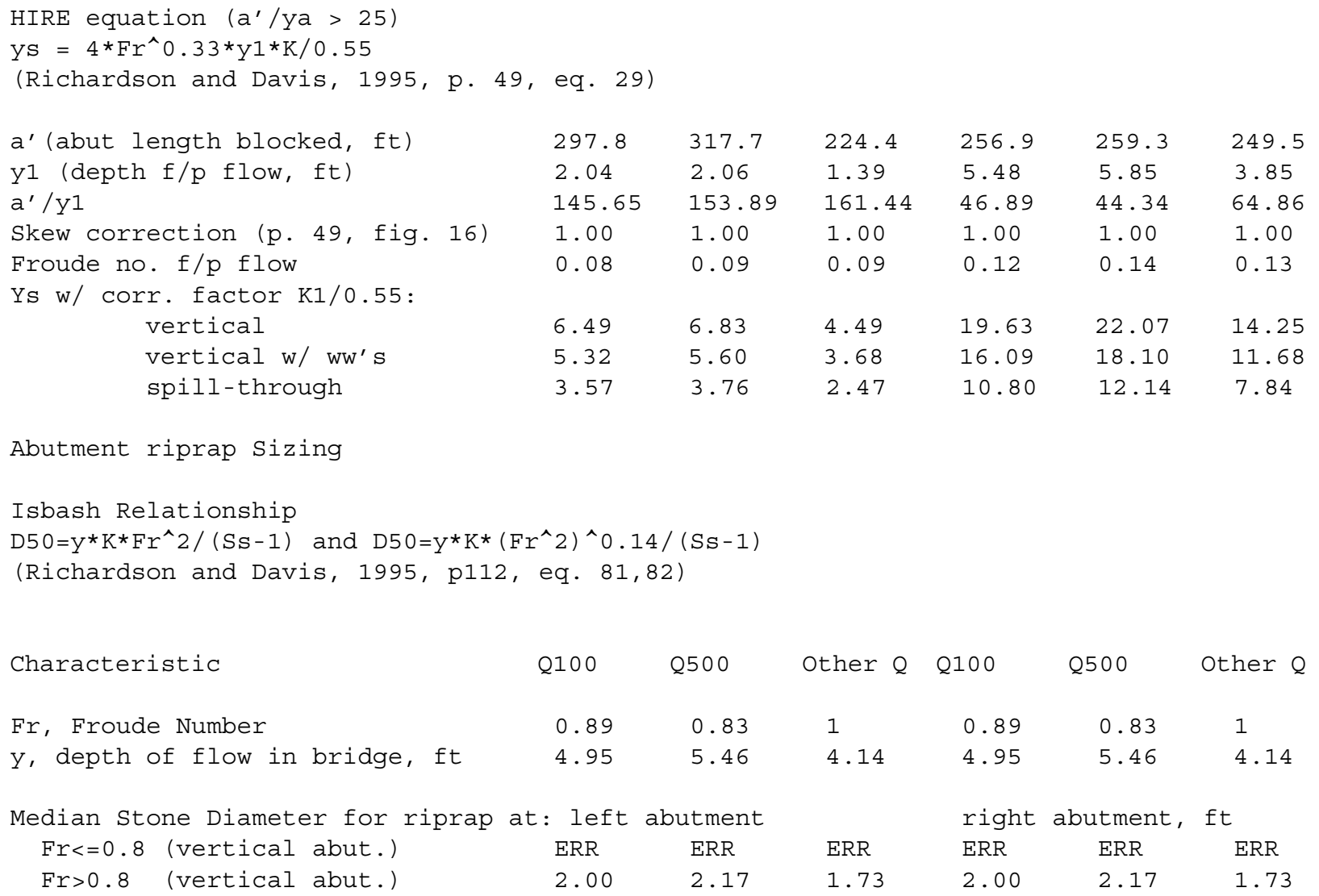


